Hamline University

DigitalCommons@Hamline

Spring 2015

\title{
Multilevel Marketing Diffusion and the Risk of Pyramid Scheme Activity: The Case of Fortune Hi-Tech Marketing in Montana
}

\author{
Stacie A. Bosley \\ Hamline University, sbosley@hamline.edu \\ Kim McKeage \\ Hamline University, kmckeage01@hamline.edu
}

Follow this and additional works at: https://digitalcommons.hamline.edu/hsb_faculty

Part of the Economics Commons, Marketing Commons, and the Public Policy Commons

\section{Recommended Citation \\ Bosley, Stacie A. and McKeage, Kim, "Multilevel Marketing Diffusion and the Risk of Pyramid Scheme Activity: The Case of Fortune Hi-Tech Marketing in Montana" (2015). School of Business All Faculty Scholarship. 2. \\ https://digitalcommons.hamline.edu/hsb_faculty/2}

This is the author's submitted copy before peer reviewed edits. The final, definitive version of this document can be found online at Journal of Public Policy \& Marketing published by the American Marketing Association. Copyright restrictions apply. doi: 10.1509/jppm.13.086

This Article is brought to you for free and open access by the School of Business at DigitalCommons@Hamline. It has been accepted for inclusion in School of Business All Faculty Scholarship by an authorized administrator of DigitalCommons@Hamline. For more information, please contact digitalcommons@hamline.edu. 
July 14, 2014

Stacie Bosley and Kim K. McKeage

Forthcoming in the Journal of Public Policy and Marketing

\title{
Multilevel marketing diffusion and the risk of pyramid scheme activity: The case of Fortune Hi-Tech Marketing in Montana
}

\begin{abstract}
While statisticians have simulated the expected rate of growth in pyramid schemes, this research examines actual data on the spread of an alleged pyramid scheme in Montana. Fortune Hi-Tech Marketing (FHTM) was a multilevel marketing firm, sued by 6 states and the Federal Trade Commission and permanently shut down in 2014. Data from a settlement with the State of Montana provides a population of participants in a geographic region with definable markets and offers unique insight into local contagion. The pattern of FHTM adoption is analyzed within a diffusion of innovation framework. Results confirm that nearly all adoption results from interpersonal influence (i.e., imitation) and indicate that participation is higher in counties with larger economic contractions. The authors add to existing guidance about early indicators of fraudulent activity and discuss intervention and prevention strategies that reflect the imitative nature of this diffusion process.
\end{abstract}

[multilevel marketing; pyramid scheme; Bass model of diffusion; public policy] 


\section{Multilevel marketing diffusion and the risk of pyramid scheme activity: The case of Fortune Hi-Tech Marketing in Montana}

Introduced in 1945, the multilevel marketing (MLM) business model "operates on the dual premise of retailing through a network of distributors and recruiting new distributors to do the same" (Keep and Vander Nat 2014, 4 and 19). This "dual premise" creates an opening for pyramid schemes veiled as multilevel marketing opportunities. State and federal regulators have acted against alleged pyramid schemes, said to be posing as legitimate MLMs. Recent examples include BurnLounge, Fortune Hi-Tech Marketing, TelexFree, CKB, and ZeekRewards (cf. http://www.ftc.gov/news-events/press-releases/2014). The Securities and Exchange Commission (SEC, https://www.sec.gov/investor/alerts/ia_pyramid.htm) and Federal Trade Commission (FTC, http://www.consumer.ftc.gov/articles/0065-multilevel-marketing) both post specific warning signs to help would-be participants distinguish legitimate MLM opportunities from fraudulent offers.

There is little academic research contributing to the understanding of this intersection of retailing and fraud, in part due to lack of reliable data. Gastwirth (1977) and Gastwirth and Bhattacharya (1984) used simulated data to determine the expected rate of growth in a pyramid scheme based on a theoretical model of scheme activity. Others have studied multilevel marketing from a specific perspective (e.g., global expansion, managerial control, buyer preferences), but few focus directly on the potential for fraud within the industry and none have had access to comprehensive micro-level data. This paper is a significant shift in that it analyzes participant data from a firm accused of pyramid scheme activity in order to better understand the juncture between fraud and person-to-person sales. 
Fortune Hi-Tech Marketing (FHTM), a multilevel marketing firm now defunct after a 2014 settlement agreement with the FTC, operated in the U.S. from 2001 to 2013. The State of Montana reached a settlement with FHTM prior to FTC action and this study uses data from that settlement, analyzing the population of Montanans who joined the firm between 2006 and early 2010. While this case study approach has limitations of being tied to a particular space and time, it has distinct advantages in that all join activity is captured in a state with definable markets and varied economic conditions. We argue that this local analysis is preferred to aggregate examination so that local dynamics are not obscured when regional data is combined. In addition, FHTM is important to examine because its business practices prompted 6 states and the FTC to investigate and take legal action, ultimately resulting in the demise of the organization and heavy losses to the founders (Federal Trade Commission et al. v. Fortune HiTech Marketing, Inc. 2014b).

Furthermore, the case itself is an interesting one to advance the study of diffusion of a business model. Lynch (1996) noted that while it may be easy to see cases where good ideas spread widely and bad ideas die out, the interesting case is one where a bad idea ends up spreading anyway (see also Dennett, 1995). As will be discussed, regulators characterize FHTM as a firm lacking competitive products/services and compensating primarily for recruitment. Analysis, both in Montana and across the U.S., shows that nearly all participants lost money and were with the company for 12 months or less. Within a diffusion of innovation framework, we analyze adoption of this alleged MLM/pyramid scheme to see if the spread over time provides insights useful for prevention and regulation. In an effort to identify early indicators of fraud, the FHTM diffusion results are compared against the growth/decline of other MLM firms. Local 
areas are analyzed for differences in diffusion based on geography and local economic conditions.

We begin with a discussion of existing literature on the intersection of multilevel marketing and pyramid scheme activity. Next, we model MLM business opportunity adoption as a diffusion process. We then apply the diffusion model to FHTM participant data in Montana and present findings from this analysis. Early warning signs are explored and we use the diffusion analysis to inform policy and consumer protection efforts. The dynamics of FHTM growth and decline suggest that early intervention is possible and that effective response must recognize the highly interpersonal nature of imitative adoption.

\section{Distinguishing Multilevel Marketing and Pyramid Schemes}

MLMs now dominate the direct selling industry in the U.S. but this was not always so. MLMs were only 25\% of member firms in the U.S. Direct Selling Association (DSA) in 1990 but accounted for $96 \%$ of the trade group by 2011 (Brodie, Stanworth and Wotruba 2002, World Federation of Direct Selling Associations 2012). This rapid change has increased the potential for pyramid scheme activity, complicating the process of separating legal from illegal commerce.

During revisions of the Business Opportunity Rule, the Federal Trade Commission (2011) noted the potential overlap between pyramid schemes and MLMs. While ultimately deciding to exclude multilevel marketing from increased regulation, the commission stated that "although there is significant concern that some pyramid schemes may masquerade as legitimate MLMs [multilevel marketing organizations], assessing the incidence of such practices is difficult and indeed, determining whether an MLM is a pyramid scheme requires a fact intensive, case-by- 
case analysis." So how are pyramid schemes defined or identified, and how might one decipher whether a particular offering is a legitimate MLM or a fraud?

Pyramid schemes come in many forms, including chain letters, gifting tables and business opportunities. Definitions vary by jurisdiction, but Keep and Vander Nat (2014) define the underlying theme as "a money-transfer scheme in which the foreseen losses of the vast majority become winnings for a small minority at the top of the recruitment structure" (10). As an example of a jurisdictional interpretation in state statute, Montana defines a "pyramid promotional scheme" as a "sales plan or operation in which a participant gives consideration for the opportunity to receive compensation derived primarily from obtaining the participation of other persons in the sales plan or operation rather than from the sale of goods or services by the participant or other persons induced to participate in the sales plan or operation by the participant" (State of Montana 2013).

As is implied by Montana's statute, a pyramid scheme can pose as an MLM by offering a product or service, creating the impression of retail intent. In a 2004 FTC Advisory opinion, commission staff stated that the presence of product or service sales does not, by itself, indicate legitimacy and defined a pyramid scheme as "a multi-level compensation system funded primarily by payments made for the right to participate in the venture" (Kohm 2004). The Advisory noted the use of mandatory product purchases as a method by which some pyramid schemes create the illusion of retail activity and seek to disguise recruitment rewards as retail commissions.

Vander Nat and Keep (2002) reviewed case law to identify guidelines for differentiating legitimate and illegitimate MLM firms. Finding the major determinant of legitimacy to be the level of genuine retail activity (as measured by sales made to consumers outside the distributor 
network, rather than to and between distributors themselves), the authors then calculated the minimum percent of retail sales needed to prevent an MLM from being identified as fraudulent. This threshold is shown to be dependent on the individual firm's operational data, namely the proportion of wholesale price attributable to production costs and "upline rewards" (i.e., commissions paid to those above the seller in the distributor network). In his expert witness testimony for Federal Trade Commission et al. v. Fortune Hi-Tech Marketing, Inc. (2013c), Vander Nat reported that at least $88 \%$ of payments made to FHTM participants were ultimately based on recruitment and virtually no goods were purchased by consumers outside the FHTM distributor network, falling well below the minimum threshold defined by Vander Nat and Keep (2002). In a more recent case, the U.S. Court of Appeals for the Ninth Circuit affirmed this recruitment vs. retail sales perspective and, in its opinion against MLM BurnLounge, quoted Vander Nat: a "pyramid scheme is an organization in which the participants obtain their monetary rewards primarily through enrolling new people into the program rather than selling goods and services to the public" (Federal Trade Commission v. BurnLounge, Inc. 2014).

As the internal data needed for such a calculation is not available to individual consumers, or possibly even most regulators, both the FTC and SEC provide warning signs of fraudulent MLM activity. These include the presence of a buy-in requirement, an emphasis on recruitment, a complex commission structure, lack of evidence of out-of-network retail sales, and promises of quick riches and long-term passive income (cf. https://www.sec.gov/investor/alerts/ia_pyramid.htm). Our research seeks to complement this advice, as well as prior research, but is not intended to provide a specific legal basis on which to differentiate legitimate MLMs from pyramid schemes (see Vander Nat and Keep (2002) and Keep and Vander Nat (2014) for a full discussion of case law in this area). Rather, this paper 
examines the growth pattern of a now-defunct MLM firm, FHTM, to provide insight for those who have to deal with MLMs that may push the boundaries or generate accusations of pyramid scheme activity - consumers, policy-makers, and regulators.

\section{A Model of MLM Adoption}

The diffusion of innovations literature provides a context and language for understanding MLM participation over time. Modelers have used diffusion of innovation models for decades to explain and predict the adoption of new products and services over time. Business process innovations and ideas, such as sustainable practices and business process re-engineering, are found to diffuse in similar fashion (O’Mahoney 2007, Peterson 2013). In utilizing the diffusion

of innovation model, we assume that participants of an MLM organization are primarily adopting the innovation of the business model, rather than the products/services offered. This would be especially true in a firm at risk of pyramid scheme activity that emphasizes recruitment and mandatory purchases over retail sales.

Looking at FHTM specifically, FTC investigation determined that most of the goods and services offered through the company were widely available from other sources and that proprietary products had close market substitutes that were less expensive (Federal Trade Commission et al. v. Fortune Hi-Tech Marketing, Inc. 2013b). Furthermore, when given a choice, over $95 \%$ of participants chose accumulation of points (used to elevate the distributor's standing to enhance recruitment rewards) over product discounts and most product purchases were made in order to qualify for recruitment rewards (Federal Trade Commission et al. v. Fortune Hi-Tech Marketing, Inc. 2013c). If true, both the product offerings and participant 
choices suggest that FHTM joiners were primarily adopting the business opportunity. This might be the case for multilevel marketing participation more broadly. A DSA website poll of over 48,000 direct sellers indicates that $85 \%$ of respondents became a direct seller to earn full or part-time income, while only $9 \%$ entered to buy products at a discount (Direct Selling Association 2014). As the overwhelming majority of direct selling organizations in the U.S. are organized as MLMs, this suggests that the primary motivation for MLM participation is to generate income and, therefore, participation is primarily an act of adopting the business opportunity.

\section{The Classical Diffusion Model}

Rogers (1976) described the "classical model" of diffusion as one that attempts to explain the adoption of a new idea where that adoption occurs by individuals over time, within a social system with embedded communication channels. The focus of the classical model is on the initial purchase/adoption decision, rather than on duration of use or repeated purchase.

Bass (1969) described adoption as occurring through two types of agents: "innovators" whose adoption is independent of the choices of others, and "imitators" whose timing of adoption is influenced by the adoption decisions of others in their social system. While adoption through innovation is driven by mass media communication, imitative adoption occurs through interpersonal communication within social networks. Given a fixed market potential, the probability of imitation is expected to rise initially with the number of cumulative adopters but eventually decline as the market becomes saturated. If MLM adoption follows these expectations, the resulting diffusion curve will have a characteristic "S-shape" as diffusion is initially slow, rises more dramatically during peak contagion, and then increases more slowly 
due to market saturation. Monthly FHTM data is analyzed to understand the relative role of innovation and imitation and to see if growth matches classical expectations of diffusion.

\section{Innovation Features}

The rate of adoption is expected to depend on the nature of the innovation itself and the suitability of the environment (i.e., social system) in which it is being adopted. Rogers (1962) identified innovation features that promote individual adoption and, therefore, aggregate diffusion. An innovation is more likely to be adopted when it is consistent with the adopter's existing set of beliefs and habits (compatibility), easy to try without great risk (trialability), attractive relative to competing innovations (relative advantage), visible to others (observability), and simple to adopt (low complexity).

MLMs utilize these features to enhance the likelihood of adoption. Compatibility is enhanced through interpersonal interaction, as the recruiter is often in the same social network and can tailor the appeal to the beliefs, habits and desires of the individual recruit. The participation agreement is structured to have a relatively small initial investment so that the recruit can try the bundle (products/services and business model) and make additional purchases/investments to sustain participation. Recruitment pitches emphasize the freedom and flexibility that can come from earning money outside of the traditional "9-to-5" workplace, stressing the disadvantages of traditional work and investment options. These schemes also promote visibility (e.g., apparel, car decals, social media activity) to be sure that adoption is apparent to the participant's social network.

Perhaps most powerfully, MLMs simplify use by offering "turnkey" training materials. Sales pitches repeat the "anyone can do it" mantra early and often. According to O'Mahoney (2007), cut-and-paste simplicity lowers adoption costs. Coupling simplicity with active replicators - 
innovation features designed for the sole purpose of supporting contagion/replication - further supports diffusion. This concept of active replication draws from epidemiological examples, such as a cold virus designed to cause sneezing. In MLMs, recruitment rewards act as an active replicator.

Diffusion does not imply benefits, and disappointment does not always lead to complaints. O’Mahoney (2007) notes that successful diffusion does not itself require that the innovation is good for the adopter, just as a cold or computer virus might spread despite harm to the host. Dennett (1995) stresses that entities replicate when they are well-designed for replication. An innovation could certainly promote adoption through increasing actual benefits conferred to the host, but this need not be the case. O'Mahoney (2007) notes the potential disconnect between the external discourse surrounding an innovation and the internal reality for adopters.

For pyramid schemes disguised as MLMs, the volume of complaints and negative word-ofmouth are often quite low. Of all fraud types monitored by the FTC, pyramid schemes have the lowest complaint rate (Anderson 2004). In the case of FHTM, of the over 3,500 Montana residents who lost money in the scheme, only 75 complaints were received. Participants are often silent about their personal internal reality due to guilt (as they have often recruited friends and family into the scheme), shame (for falling prey to a get-rich-quick scheme or for feeling that they failed as an entrepreneur), obligation or loyalty (based on close ties with one's recruiter), and/or hope that continued scheme activity might increase the likelihood of a personal return on investment - silence is used as a self-concept and impression management strategy (Goffman 1952).

There can also be pressure from one's "upline" (i.e., those above you in the distributor hierarchy) to stay with the organization, communicated through messages like "the only way to 
lose is to quit" and "fake it "til you make it." MLM distributor agreements sometimes include arbitration clauses which can limit a participant's access to outside resolution through courts or regulatory bodies. From an assumption of neoclassical economic rationality, consumers might determine that the expected benefit of filing a complaint is exceeded by the anticipated cost.

Finally, complex compensation structures can obfuscate a participant's understanding of his/her internal reality and may further contribute to silence. Pratt (2000) found that MLM distributors were often unable to state their net earnings and, furthermore, that distributors could not agree on the method by which they should calculate the returns to their labor. Conversion of gross to net earnings is complicated by many factors: joining and renewal fees, complex bonus structures, unmeasured time and travel expenses, payments for training materials, conventions, selling aids, and incentivized internal consumption.

\section{Innovation Environment}

While content and design are critical to innovation adoption and diffusion, the environment also determines the innovation's success. O'Mahoney (2007) likens the former to a seed and the latter to the fertility of the ground in which it is planted. One key environmental factor is network density, both social and geographic. Haggith et al. (2003) found that dense networks best support diffusion of innovations, especially when those innovations are adopted through the imitation of ideas. MLM adoption and diffusion are expected to increase with population density as transaction costs are reduced and the sheer number of prospects (assumed to be some function of the number of people living within a certain distance) increases, especially if imitation occurs through face-to-face interaction between participant and potential recruits. To address both population density and the possibility of variation in diffusion timing across markets, we look at the data for the Billings metropolitan market separately from the data for the 
rest of Montana. Other counties and regions were also analyzed for differences, but no significant variation emerged outside of the Billings metro area.

Local economic conditions are also expected to impact adoption. Cahn $(2006,2008)$ and Casanova (2011) found that participation in multilevel marketing was motivated by limited access to formal labor markets and the need to supplement household earnings. This could mean that participant interest grows during recessionary periods, when alternative opportunities for labor and capital investment are depressed. For multilevel marketing firms with significant retail sales, however, the potential recruit would need to consider the potential entry of other sellers in the same market as well as the possible reduction in demand for the product/service offered (unless those offerings are comprised of inferior goods). As the focus of MLM-based pyramid schemes falls on recruitment over sales, they may not follow the trajectory of legitimate retail firms. The analysis that follows provides some preliminary evidence that recruitment is stronger in locations with weaker economic conditions and that FHTM in Montana was affected differently by the recession than many other MLM firms.

The landscape for multilevel marketing could also be affected by a country or region's retail environment. Areas with insufficient retail infrastructure will likely be more receptive to direct selling, as the availability of substitutes is limited (Biggart 1990, Schwartz 1992). This provides an opening for pyramid schemes disguised as MLM business opportunities. For fraudulent offerings, legal and financial systems also affect the climate for scheme growth. Jarvis (1999) pointed to Albania's weak formal financial system and legal infrastructure as preconditions for the catastrophic effects of pyramid schemes there in the 1990s. Verdery (1995) cited Romania's history of hyperinflation, plummeting real incomes, and tight credit as some of the factors encouraging massive participation in over 100 schemes between 1990 and 1994. Given that our 
data is restricted to a single U.S. state over a four year time frame, we do not expect that any significant changes in the legal or financial infrastructure were affecting participation. We expect that, if anything, the Montana retail environment between 2006 and 2010 became more competitive as e-commerce offerings expanded and might have modestly reduced the appeal of FHTM.

\section{Methodology}

Given that features of both the environment and the innovation drive the degree to which adoption occurs within a social network, how can we expect an MLM to spread in a certain place and time period? The classical diffusion model addresses this question, assuming that diffusion occurs through adoption by innovators and imitators. The Bass Model, as described by Mahajan, Muller and Bass (1995), assumes that the probability of adoption in a given time period is dependent on the likelihood of innovation and imitation in the following way:

if $n(t)$ is the number of new adopters at time t, $N(t)$ is the number of cumulative adopters as of time $\mathrm{t}$ (i.e., all those who adopted prior to time $\mathrm{t}$ ), $m$ is market potential, $p$ is the coefficient of innovation (or external influence), and $q$ is the coefficient of imitation (or internal influence), then

$$
\operatorname{Pr}\left(\text { Adoption }_{\mathrm{t}}\right)=\mathrm{n}(\mathrm{t}) /(\mathrm{m}-\mathrm{N}(\mathrm{t}))=\operatorname{Pr}(\text { Innovation })+\operatorname{Pr}\left(\operatorname{Imitation~}_{\mathrm{t}}\right)=\mathrm{p}+\mathrm{q}(\mathrm{N}(\mathrm{t}) / \mathrm{m})
$$

Rearranging (1) yields the following:

$$
\mathrm{n}(\mathrm{t})=[\mathrm{m}-\mathrm{N}(\mathrm{t})][\mathrm{p}+\mathrm{q}(\mathrm{N}(\mathrm{t}) / \mathrm{m})]
$$

and

$$
\mathrm{n}(\mathrm{t})=\mathrm{pm}+(\mathrm{q}-\mathrm{p}) \mathrm{N}(\mathrm{t})-(\mathrm{q} / \mathrm{m})(\mathrm{N}(\mathrm{t}))^{2}
$$


This research applies equation (2b) to the population of FHTM participants in Montana. Given that the data are from an alleged MLM pyramid scheme, diffusion is expected to be driven primarily by imitation, as measured by the relative importance of $q$ over $p$. There was relatively little direct contact between the company and potential recruits/adopters and virtually all recruitment is assumed to have occurred through interpersonal communication within social networks, limiting the role of external influence on adoption. Given the importance of interpersonal influence, the spread of the network should reflect a contagion pattern conforming to the Bass model as explored in other market contexts and the timing of diffusion is not necessarily expected to be uniform across the state. Lastly, FHTM activity is expected to respond to local economic conditions with larger economic contractions during this recessionary time period corresponding to higher levels of adoption.

Predicted monthly joins/adoptions, $n(t)$, are estimated using OLS regression where equation (2b) is estimated as:

$$
n(t)=b_{0}+b_{1} N(t)+b_{2} N(t)^{2}+\varepsilon(t)
$$

The parabolic shape generates an estimate of $m$, where predicted new joins become zero due to market saturation. Using $m$ and the regression coefficients, the coefficient of innovation $(p)$ and the coefficient of imitation $(q)$ are derived. Statistical significance of $p$ is determined by evaluating the statistical significance of the regression intercept term, $b_{0}$, since we know $m$ to be non-zero. If $p$ is statistically insignificant, then the statistical significance of $q$ can be determined based on the significance of $b_{1}$. We present the results of this analysis after describing FHTM participant data from Montana.

\section{Data and Results}




\section{Participant Data}

FHTM, founded in 2001, operated as a multilevel marketing company in the United States, Canada, and Puerto Rico and, by early 2013, recruited over 500,000 people in the U.S. alone. Over the last few years, the company has settled state-level lawsuits with Montana, Texas and North Dakota. The State of Montana alleged the following in Montana v. Fortune Hi-Tech Marketing, Inc. (2010):

"FTHM is not a multilevel distribution company, but rather a pyramid promotional scheme because the compensation each participant in the program receives is derived primarily from obtaining the participation of other persons in the program and not the sale of goods and services."

During its time in operation, the company recruited "Independent Representatives" who paid (typically \$299) to join the company, with additional fees for training and yearly renewal. Representatives were to earn compensation based on recruitment of others and on commissions for products/services sold. The company website advertised approximately 20 products/services that could be purchased through FHTM - the most high profile of these being Dish Network satellite service. For most of these offerings the company was operating as a third-party vendor, advertising access to pre-existing goods and services such as TaxBot and Amusement Pack. In Federal Trade Commission et al. v. Fortune Hi-Tech Marketing, Inc. (2013a), investigators reported that FHTM could not offer a discount on any of these goods and sales commissions were extremely small (e.g., \$0.80 on a Dish Network package). While FHTM distributors could earn commissions on retail sales made by their downline recruits, these were a fraction of the 
original sales commission (e.g., $\$ 0.08$, or $1 / 10^{\text {th }}$ of the commission, on a Dish Network package sold by a downline recruit).

While denying any wrongdoing, the company agreed to pay $\$ 1$ million in a 2010 settlement with the State of Montana and up to \$1.3 million in a 2011 settlement with the State of Texas, where settlement money was used to fund refunds to participants. Subsequent events have closed the company. On January 28, 2013 the Federal Trade Commission and three state attorneys general (Kentucky, Illinois and North Carolina) announced a shutdown of the firm, pending trial on charges of exaggerated earnings claims and pyramid scheme activity. In May of 2014, a settlement order was filed. The settlement stipulates that, while admitting no wrongdoing, FHTM is permanently closed and founders are banned from all future multilevel marketing activity of any kind (Federal Trade Commission et al. v. Fortune Hi-Tech Marketing, Inc. 2014b). The financial judgment also allows for some refunds to consumers across the country. This settlement result is typical of the FTC's approach to halting pyramid scheme activity. In a recent review of past FTC pyramid scheme cases, 12 of 14 reached a settlement prior to trial and, in all 12 settlements, the defendants did not admit liability (D. Brooks, personal communication, June 11, 2014). In each of these settlements, Brooks notes that defendants agreed to stipulations "which generally include injunctions against participating in prohibited marketing practices, disclosure and record keeping requirements, and financial redress." In the FHTM case, a new deterrent was generated when the court authorized clawback ligation against highly compensated FHTM participants, beyond the company founders (Federal Trade Commission et al. v. Fortune Hi-Tech Marketing, Inc. 2014a).

The data for this research is the result of the company's settlement with the State of Montana, provided by Montana's Deputy Securities Commissioner. While personal information was 
redacted, the dataset provides location, recruitment date, fees paid and yearly commissions earned for all 3,737 FHTM independent representatives in Montana, recruited between the start of 2006 and March $10^{\text {th }}$ of 2010 (Temporary Cease and Desist order issued in March, 2010). While data showing specific recruitment lines would be useful for network analysis purposes, since that data is not available our study seeks to measure the rate of imitation (or contagion) within a geographic region which can be estimated without such direct network link data. We believe this to be the first dataset of its kind, made available for research, which provides individual participant data for an alleged pyramid scheme.

Total net earnings over the four years were computed for all individual distributors as sales commissions less joining, training and renewal fees reported by the company. It is important to note that any additional business-related expenses or product purchase for the purpose of rewards qualification would reduce these net earnings further, but that data is not available. As an illustration of the dataset, Table 1 displays information for the 10 highest net earners in Montana in addition to the 10 lowest net earners. Figure 1 then displays summary net earnings information for all participants in Montana over this time period.

Insert Table 1 about here

Insert Figure 1 about here

Some similarities are evident among the representatives with high net earnings. The top four earners, who capture nearly half $(48.4 \%)$ of all positive net earnings in this dataset, entered the business in 2006 or 2007 and resided in the largest population centers in the state ( 3 of the 4 in Billings, the most populated city in the state). Nearly all of the twenty-one $+\$ 10,000$ earners were residing in or around the largest cities in the state. Probabilistically, it is more likely that a 
representative will reside in a larger population center and the location's density might also support earnings if it brings dense social networks and reduced transaction costs.

The pyramid-like earnings structure is readily apparent in Figure 1. On average, the $94 \%$ of participants at the "bottom of the pyramid" earned \$39 in commissions to slightly offset the \$299 joining fee for a net loss of $\$ 260$. Only 3\% of all distributors paid renewal fees, meaning that $97 \%$ of recruits were out of the organization within one year of joining. Table 2 demonstrates the outcomes for participants who entered in different time periods. As expected, earnings and duration of participation declined for later adopters. These results correspond with the national data on FHTM participants between 2009 and 2012. Over this time period, approximately 96\% of participants earned less than $\$ 299$ and the renewal rate fell from 5.8\% to 2.4\% (Federal Trade Commission et al. v. Fortune Hi-Tech Marketing, Inc. 2013d).

Insert Table 2 about here

\section{Results of Diffusion Analysis}

Figure 2 depicts the new adoptions each month as well as the diffusion measured in cumulative joins between June, 2006 and February, 2010 (the last full month of data available). It is evident that the MLM had not reached saturation state-wide at the time that the company's operations were halted in Montana, providing incomplete data for model estimation. Within the state, however, the Billings metro area does appear to have experienced its peak adoption period prior to the regulatory action, as depicted in Figure 3 (adoption in Billings vs. the rest of the state). We proceed with an analysis of the Billings region, the largest population center representing $42 \%$ of all FHTM joins. We then draw implications for the remainder of the state.

Insert Figure 2 about here

Insert Figure 3 about here 
Figure 4 depicts the Bass Model analysis, with the tick-marked line mapping the predicted joins against actual joins for the Billings metro. The region appears to have experienced two waves or cycles of adoption generating a functional discontinuity: cycle I from June, 2006 to December, 2008 and cycle II from the end of December onward. There are multiple possible triggers for the second cycle. The recession could have caused a new wave of interest in nontraditional earnings and investment options. There were also four new recruits who joined late in 2008 who ultimately earned substantial sums, all located in a small zip code in the northwest corner of the Billings metro. This cohort of new aggressive distributors, acting as meme fountains (Blackmore, 2000, 163) might have helped launch the second cycle, inspiring higher levels of imitation. If we treat the two cycles separately (similar to two successive rounds of the flu), we can get a better sense of the adoption pattern and related parameters for each cycle, as seen in Figures 5 and 6.

Insert Figure 4 about here

Insert Figure 5 about here

Insert Figure 6 about here

Since the innovation coefficient $(p)$ is statistically insignificant in every case $\left(H_{o}: b_{0}=p m=0\right.$ is not rejected), we can conclude that FHTM adoption occurred through interpersonal influence rather than through direct appeals from the company to individual recruits. Furthermore, the coefficient of imitation is larger for the second cycle than for the first. The $q$ values, 0.276 and 0.475, fall in or near the expected range of 0.3-0.5 found in the diffusion literature (Mahajan, Muller and Bass 1995). The peak level of contagion/imitation in the first cycle comes when there are 300 existing adopters. With this level of diffusion the model predicts 45 new adoptions 
in the subsequent time period and no additional joins are expected once there have been 607 adopters $(m)$. The second cycle is shorter and more potent. Peak contagion occurs when there are 515 cumulative joins (prompting 130 adoptions in the subsequent time period) and diffusion is expected to stop at 1,050 recruits. Note that, especially in the second wave, the number of new monthly recruits falls off very quickly after reaching the peak adoption period. The three estimated parameters $(p, q$, and $m)$ can be used to predict the rest of the diffusion cycle, resulting in a declining curve for new joins with cumulative membership leveling off.

Turning our attention to the remainder of Montana, we use the Billings results to inform a possible diffusion scenario for the rest of the state, in the absence of court intervention. As Huang and Chen (2010) note, diffusion studies often utilize parameters (especially $m$ ) from another product or region to generate predictions for instances when peak adoption has not yet occurred. Looking back to Figure 3, the Billings and out-state experiences were somewhat alike in the first three years of FHTM activity, with Billings experiencing a stronger wave of adoption in the second year relative to the rest of the state. Their adoption patterns diverged in year four, as the Billings area joins declined while adoption accelerated in the rest of the state.

If we make the assumption that the Billings region was, in fact, approaching saturation and we look at the total diffusion in this region, adoptions represented approximately $1 \%$ of the Billings metro population. For illustrative purposes, we predict adoption outside of the Billings region assuming that market potential $(\mathrm{m})$ is similarly $1 \%$ of the population (or 8,674 total joiners). Choosing $\mathrm{p}$ to reflect initial joins and selecting $\mathrm{q}$ to minimize mean squared error results in $p=0.002$ and $q=0.16$. Figure 7 displays the actual join data against Bass Model predictions using these parameters. It may be the case that this scenario overestimates out-state diffusion given that Billings has higher population density than the remainder of the state. On the other hand, 
the model clearly underestimates new adoptions in February, 2010 so diffusion could have exceeded that predicted in Figure 7. In either case, it is reasonable to expect that state action limited future losses. Both the litigation activity and the settlement restrictions on future FHTM operations would be expected to lessen future participation in the company in Montana. In an extreme, if state action deterred all future joins our analysis shows that an estimated 7,000 outstate residents would be prevented from joining. If we assume that $94 \%$ of recruits lose an average of $\$ 260$, this translates to avoidance of $\$ 1.7$ million in consumer loss. Any reduction in participation, generated by the state action, would shift the diffusion curve downward. While most of the damage might have already been done in the state's largest city, the intervention almost certainly reduced loss elsewhere.

Insert Figure 7 about here

To explore the role of the innovation environment, we also examined adoption in out-state counties under different economic conditions. From 2006-2010, each county in Montana experienced an increase in its unemployment rate. The median rate increase was $2.8 \%$ points, with a maximum and minimum of $9.7 \%$ and $0.9 \%$ points, respectively. Figure 8 depicts FHTM adoption in counties below the median (i.e., experiencing less dramatic economic contractions) and in counties at or above the median unemployment rate increase. As expected, adoption was higher in counties experiencing larger economic contractions. This difference was not attributable to higher population or population density in those depressed counties, so it is reasonable to conclude that this result is related to economic conditions. This suggests that special attention be paid to those regions experiencing pronounced contractions, as they may be most vulnerable to scheme contagion.

Insert Figure 8 about here 
The diffusion analysis provides useful findings on the nature of FHTM adoption and growth. First, this alleged pyramid scheme did spread in a way consistent with the Bass model as driven by imitation (i.e., internal influence). Second, the imitation coefficients estimated generally fit within the norms of the diffusion literature but vary by adoption wave and region. Third, in a fixed geographic region (Billings), adoption accelerated rapidly, peaked, and decelerated rapidly as well, similar to a fad. Furthermore, it is possible to have multiple cycles of adoption. Lastly, the economic environment appears to affect adoption, and the timing of FHTM diffusion varied within the state.

Montana may be atypical in certain ways (e.g., low population density, high degree of homogeneity) but the relatively sparse population was beneficial in analyzing definable markets. It would be informative to estimate parameters for others regions or alleged schemes for comparison purposes. Following Huang and Chen (2010), examination of environmental factors such as income, education, and culture could provide even more insight for policy and consumer protection efforts. We have not provided guidance on predicting multiple waves of activity. While the policy implications are not necessarily sensitive to the number of adoption cycles, further study might help identify triggers for additional waves of adoption.

\section{Comparison to other Multilevel Marketing Firms}

Do these results present any aspects of diffusion that are unique to an alleged pyramid scheme? In the interest of identifying distinctions that might serve as early warning signs, we compare the growth of FHTM with other multilevel marketing firms over this same time period (2006 through quarter 1 of 2010). Quarterly revenue data was obtained from SEC filings for 10 publicly traded MLM firms. While most of these firms operate in multiple countries, U.S. revenue was identified in most cases and North American revenue was reported for two firms when U.S. revenue was unavailable. For each firm, we estimate a time series regression 
equation. If $Y_{t}$ represents company revenue in quarter $\mathrm{t}, T_{t}$ captures time trend, $R_{t}$ is a dummy variable indicating a recessionary quarter, and $Q_{t}$ is comprised of quarter dummy variables to capture seasonal variability, then

$$
Y_{t}=b_{0}+b_{1} T_{t}+b_{2} R_{t}+b_{3} Q_{t}+\varepsilon_{t}
$$

As we do not have national or state-level FHTM revenue over this time period, revenue from join fees per quarter were calculated in Montana. Given that genuine retail sales were modest and most sales were connected to rewards qualification, we expect join fee revenue to be highly correlated with overall FHTM revenue in the state each quarter. Table 3 depicts regression output for these firms.

\section{Insert Table 3 about here}

Of the 10 MLM firms analyzed, all had statistically significant linear time trends and half were experiencing a downward trend in sales between 2006 and early 2010. None of those 5 firms with declining revenues over time had a statistically significant coefficient on the recession variable, indicating that the downward trajectory might be interrupted by seasonal variability but was not significantly altered by the nationwide recession (at least not as defined by the technical peak and trough for the nation). For FHTM and the 5 comparator firms with a positive time trend, the linear model was compared to the log-linear to check for nonlinear revenue growth, and the best specification was chosen based on Royston and Goldstein's (1993) transformed Rsquared method. Focusing on the time trend, FHTM was one of four firms with nonlinear positive growth and had a per-quarter growth rate of 33\%. The firm experiencing the next-fastest growth exhibited a rate of only $8 \%$ per quarter. Aside from this upward trend, two of the four firms with positive, nonlinear time trend saw significantly lower growth during recessionary quarters, but FHTM did not exhibit this tendency. While the recession did not generate a 
statistically significant boost in join fee revenue, results indicate that the recession did not hinder FHTM growth in Montana.

Differences observed might be the result of the local versus aggregate nature of the data analyzed as FHTM is observed in a single state whereas comparative data is captured at the national or international level. Within that large scale data, it is possible that these MLM firms also experienced bursts of activity in certain markets contemporaneous with declines in others. However, this analysis highlights Montana's experience with FHTM and how that experience contrasts with a broader picture of other MLMs. Differences reveal a warning sign of potential fraud that is best observed at a local level: a continuous innovation with exponential growth, coupled with uninterrupted adoption during a recession. In fact, as previously mentioned, FHTM adoption was higher in counties with larger increases in unemployment. Diffusion analysis at a local level also demonstrated rapid decline in adoption, not seen in this aggregate MLM data.

These findings add to current warning signs promulgated by federal regulators and prior research, summarized in Table 4. Some findings of FHTM outcomes, specifically high turnover and losses to most participants, are consistent with FTC warnings. Added findings on diffusion characteristics add to the body of knowledge. While FHTM adoption dynamics do not identify a bright line legal determinant, they do add to the qualitative characteristics investigators could look for when examining individual MLM activity, especially at the local level. These same findings could be useful, if properly reframed, for consumer education efforts.

Insert Table 4 about here

\section{Implications and Recommendations}


Consumer issues are widely addressed through three basic mechanisms: regulation, consumer education, and industry self-regulation (McGregor 2012). The use of such mechanisms to address the complexities of MLM systems is discussed in this section, with emphasis on regulation and consumer education.

Just as monitoring and inoculation systems seek to control epidemiological outbreaks, such systems are needed to identify and prevent pyramid scheme diffusion. An understanding of diffusion dynamics can inform policies and procedures in terms of both prevention and intervention. We use FHTM as a case study to discuss recommendations, as it was alleged to be a pyramid scheme by 6 states and the FTC, nearly all participants lost money, and the majority of activity centered on recruitment. State action in early 2010 likely disrupted the diffusion cycle outside of the Billings region, averting significant consumer losses.

By the time the FTC took action against the company in early 2013, expert witness Vander Nat conservatively estimated consumer losses to be \$169 million (Federal Trade Commission et al. v. Fortune Hi-Tech Marketing Inc. 2013c). The court appointed receiver reported that national participation in FHTM was already declining by 2012, as the number of new representatives in the U.S. fell from 97,323 in 2010 to 47,667 in 2012 (Federal Trade Commission et al. v. Fortune Hi-Tech Marketing Inc. 2013d). While regulatory action prevented additional harm and the potential for new waves of FHTM activity, this data suggests that adoption was slowing and that significant consumer losses could have been avoided by earlier intervention. With the understanding that resources and information are limited, how can the FHTM diffusion analysis inform future action?

\section{Fraud Identification}


The diffusion analyses in Montana indicate an early incubation period where FHTM activity remained relatively low. As participation was found to be driven by imitation, rather than innovation, it took time for FHTM to gain traction in the state. Had innovative adoption played a more dominant role, there would likely have been increased activity in the early months after introduction. While this finding might confirm expectations, this is the first data to demonstrate and measure the imitative nature of diffusion of an MLM, alleged to be a pyramid scheme. It suggests that aggressive response could reap large rewards, in the form of averted consumer losses, if fraudulent activity is halted prior to the period of exponential growth. In addition, the Billings region provides an example of multiple waves of adoption where information from a first wave could be used to prevent successive waves. As previously discussed, pyramid scheme victims are often quite silent. This knowledge of relative silence, combined with the diffusion curve characteristics, suggests that early MLM complaints should be taken extremely seriously. In an environment of competing public interests and limited enforcement resources, the FHTM analysis provides support for resource allocation in the face of just a limited number of complaints, as outlined below.

When receiving a complaint, a first step would be to check for complaints filed with other agencies or in other regions. The FTC's Consumer Sentinel Complaint System is a fraud complaint aggregator, bringing together complaints from states, the Better Business Bureau, and other sources. In 2012, the system contained only 2,922 complaints on MLMs/chain letters/pyramid schemes and only 9 states contributed data to the system (Federal Trade Commission 2013a). If all states participated in this network, early local-level complaints could be compared against activity in other areas. Note that the imitative nature of adoption is responsible for the varying timing of diffusion across regions. If FHTM adoption had been 
innovative, diffusion could have occurred more uniformly across the state of Montana. In some ways, the imitative nature is a benefit (from a consumer protection point of view) in that social networks are likely to be impacted at different times, again providing an opportunity for early detection and intervention.

Kentucky Attorney General Jack Conway noted the importance of looking to the experience of other regions when determining whether to investigate an MLM firm. He reported that his state's investigation of FHTM began in the summer of 2010, after noticing that both North Dakota and Montana had taken regulatory action against FHTM. At that time, his office had received "about a dozen complaints" against the company (Federal Trade Commission 2013b). Complaint aggregation would support information flow between regions, even before regulatory action is taken by a state.

After a complaint has been received, and especially if complaints appear in other regions, the company's compensation plan and other company documentation should be reviewed for warning signs. This review could also occur at the time of registration, if the state requires such a registration (as Montana now does). Both the SEC and FTC warn consumers to watch for complicated incentive plans that incentivize recruitment over retail sales and to be skeptical of excessive earnings claims, especially those that promise quick returns and passive income. Despite these warnings, it is not clear that regulators at the state or national level routinely examine company information. In reviewing FHTM's compensation plan, Vander Nat reported that recruitment rewards outpaced product commissions at a rate ranging from 25/1 up to 42/1 dollars, depending on participant rank in the organization (Federal Trade Commission et al. v. Fortune Hi-Tech Marketing, Inc. 2013c). Vander Nat also noted the misleading nature of the firm's earnings disclosure statement, as it left off the majority of participants who earned no 
compensation. Company literature and promotions were also found to promise quick and easy wealth with long term residual income. The 2013 FTC complaint against FHTM cites many such examples, including a distributor testimonial claiming over $\$ 50,000$ in earnings in his six months with FHTM and the presentation of a \$64 million mock check awarded to the top 30 earners at a national convention.

Training could be provided by experts in fraud detection to state-level investigators to better equip local regulators to identify hallmarks of fraud. The FTC headquarters and regional offices could work more consistently with states, supporting local efforts, as individual states often lack the resources and expertise needed to pursue such investigations. After action was taken against FHTM by other states, the FTC's Midwest Region office supported Kentucky, North Carolina and Illinois. Relatively few cases have been pursued at the state or federal level and cooperation of this type can support additional action against suspect firms.

Tighter disclosure requirements would also support consumer protection, as FHTM-like earnings and retention outcomes would be more evident. While there might be no specific bright line between a legal earnings structure and an illegal one, it would presumably be a reasonable ingredient in determining which firms to scrutinize more closely (more on disclosure requirements in the next section). If such data is available via tax filings or registration requirements, states should also look for activity that is outside the norm of traditional retail growth. The FHTM analysis suggests that "unusual activity" includes spikes in participation, growth despite a recession, and elevated growth in depressed regions.

\section{Consumer Education}

Adkins and Ozanne (2005) note that consumer literacy "includes such knowledge as understanding consumer rights and marketing practices, having the interpersonal skills to 
manage service encounters and make complaints, and asserting one's voice and achieving agency in the marketplace." (154). McGregor (2000) includes three areas in consumer literacy: decision making, resource management, and citizenship. The choice to participate in a MLM opportunity encompasses all three of these as the consumer makes a decision about this option among others, there are implications for the consumer's personal finances, and unscrupulous schemes generate the need for consumer protection. One tenet underlying consumer education is that consumers should be able to make good decisions "based on reliable information" (McGregor 2005, 438). The dearth of information available in some of these schemes violates this underpinning, and in the case of consumption opportunities that also serve as business investments, consumer protection suggests that the standard for literacy should be especially high.

In concert with more aggressive detection and intervention, preventative measures might help the public achieve this higher level of economic literacy, leading to better decision making, at least for decision makers at the margin. This is especially relevant when diffusion occurs through imitation, as was demonstrated for FHTM. If adoption is an act of innovation, education works at an individual level to prevent personal participation. When adoption is an act of imitation, education that prevents a single join can thwart further adoption within that same social network, generating a higher return on the educational investment.

Enhanced financial literacy is one approach to arming consumers against fraudulent schemes. FTC statistics reveal that victims of income-related fraud (which includes business opportunity, work-at-home and pyramid scheme fraud) are most likely to be aged 18-24 and have some college or have completed a college degree (Anderson 2013). This provides an opening for 
secondary and post-secondary institutions to offer financial literacy programming through courses or co-curricular offerings.

The call for more widespread consumer education in secondary schools is part of a growing trend in the U.S. According to Walstad, Rebek and MacDonald (2010), as of 2009 forty-four states had developed educational content standards in the area of personal finance, and thirteen states required completion of a course including material on personal finance for high school graduation. Their study demonstrated gains in financial knowledge among high school students based on financial literacy education, in areas including financial decisions, human capital, risk and reward, and decision making. Moving beyond short-term learning gains, Grimes, Rogers and Smith (2010) reported that educational experiences in economics/personal finance are associated with consumers' opening and maintaining a bank account, showing that the effects are behavioral as well as conceptual. In their study, the impact of a high school class was almost as large as that of learning in college. Given the much broader exposure to high-school level education, continued initiatives at that level are warranted but should be expanded to discuss pyramid scheme fraud.

In addition to exposition on the warning signs of fraud, such programming should discuss the use of social networks and sophisticated persuasion tactics to promote adoption and diffusion. In "affinity fraud," schemes capitalize on trust built up within tightly knit social networks, such as religious, racial or ethnic groups (Fairfax 2001, Perry and Brody 2011). Recruitment within a high-trust social network can serve to reduce skepticism and capitalize on feeling of obligation or allegiance to the group and its members (Lynch 1996, Cialdini 2001). Again, the use of affinity groups for fraud promotion is all the more potent when adoption occurs through imitation. Consumers can, however, be educated to identify the effects these tactics are having on them, 
and counteract them with cognitive strategies that engage more rational decision making frameworks (Cialdini 2001).

Literacy efforts could also emphasize the characteristics of likely victims. FTC statistics show that victims of income-related fraud are more likely to report risky purchasing behavior (i.e., buying from an unknown or unreliable source in the past) and self-report as optimistic and risk-seeking (Anderson 2013). Knowledge of risk factors could prove useful in discussing personal vulnerability.

\section{Information Disclosure}

Beyond preventative measures to improve the financial literacy of potential victims, inoculation could also be embedded within the marketing message itself. Redmond (1996) noted that public policy can attempt to impact adoption of harmful products by altering the "product" (e.g., labeling requirements) or the person (e.g., educating the adopter or those in his/her social network). We suggest product alteration through an enhanced disclosure document, presented at the time of recruitment and again before renewal. For new MLM firms, such disclosure could be required after one year of operation.

Fischer et al. (2008) found that decision-makers are more cautious and seek more diverse information when they are focused on potential losses. Gain-framing tactics that focus attention on potential gains (and minimize discussion of losses) motivate confirmatory information search and, as a result, stimulate participation. MLM promotional materials often capitalize on this tendency, presenting a selective and biased set of past earnings information that reflect the subset of participants who reached a particular minimum threshold of participation and earnings. All MLM firms should be required to present an earnings disclosure statement that includes earnings (net of fees paid to the firm, as in Figure 1) and retention rates for all past participants, regardless 
of earnings level or status. Consistent with FTC and SEC warnings to consumers, the company should also be required to disclose evidence of retail sales outside the distributor network, provide a listing of existing company distributors within the recruit's home market, and present information on current and past litigation against the company. Once again, in an imitative process, deterrence of one can mean averted harm for many.

While there is much research suggesting the limits of information disclosure in affecting consumer decision making, Garrison et al. (2012) sets forth a process for creating a disclosure that is most likely to increase information retention. This includes careful attention to design aspects (e.g., word selection, layout, framing, and context) as well to a consumer testing process with focus groups and other complementary methods. In the context of payday borrowing, Bertrand and Morse (2011) also find differences in altered consumer behavior based on disclosure attributes. They find that consumers respond most to disclosures that indicate the "over time" cost to use. The MLM disclosure should be research-informed and tested for consumer efficacy, potentially emphasizing the cost of long term participation.

\section{Cooling-Off}

Lastly, research points to the role of urgency in scam recruitment, encouraging decisionmaking during "hot" rather than "cold" moments to limit information search and processing (Langenderfer and Shimp 2001). While it is hoped that a potential recruit would conduct necessary research prior to joining, many recruits will succumb to interpersonal influence and urgency and sign on, but use the current 3-day "cooling-off period" to re-evaluate that decision based on further deliberation. The FTC is currently considering a proposal to alter the existing cooling-off period regulation (Federal Trade Commission 2012). The change would lift the exclusionary limit from $\$ 25$ to $\$ 130$, as the original limit was established in the early 1970 s. The 
FTC itself notes the difficulty in differentiating fraudulent pyramid schemes from legitimate MLM firms and suggests multiple deliberative steps, including researching the company and seeking the advice of a friend or advisor. Based on the demonstrated importance of interpersonal influence (i.e., imitation) in scheme recruitment and the speed with which it can spread, we suggest that the FTC maintain the existing exclusionary limit to maintain current levels of coverage. Individual states or the FTC could also require a longer cooling off period for multilevel marketing business opportunities, as was done in Montana.

\section{Conclusion}

In analyzing FHTM participant data in Montana within a diffusion of innovation framework, we have found that adoption was highly imitative and non-linear. Furthermore, both the timing of the diffusion cycle and the coefficient of imitation varied across time and region and the most populated region experienced multiple waves of adoption. The business opportunity was more readily adopted in counties with larger economic contractions and is differentiated from other MLM firms in that it experienced aggressive exponential growth and continued to grow during the national recession. We use these diffusion findings to suggest changes to monitoring and intervention systems (e.g., complaint aggregation, enhanced training for state investigators, and strengthened partnerships between states and FTC regional offices), aimed at early identification of fraud based on local activity. Findings also inform new prevention efforts, including consumer education programs and enhanced disclosure requirements, intended to introduce friction in imitation. Lastly, we recommend maintenance of the existing cooling-off period given the role of interpersonal influence in recruitment. 
This research expands upon questions of MLM legitimacy to directly analyze adoption of an alleged pyramid scheme with the goal of developing proactive interventions. We do not suggest that a diffusion curve would necessarily be useful in a court setting, but rather that the FHTM diffusion pattern has helped to identify a set of policies and processes that could trigger fraud inquiries in a more systematic and timely fashion. Our analysis does not overstate the financial risks - indeed, our data lends itself to a conservative estimate of losses as we do not have data on product purchases made for plan qualification or other business expenses outside of join and renewal fees. This research sheds some light on an often invisible phenomenon, hopefully prompting discussion and additional research on pyramid scheme activity and ways to best protect citizens from these fraudulent offerings disguised as MLM business opportunities. 


\section{References}

Adkins, Natalie Ross and Julie L. Ozanne (2005), "Critical Consumer Education: Empowering the Low-Literate Consumer," Journal of Macromarketing, 25(2), 153-162.

Anderson, Keith B. (2004), “Consumer Fraud in the United States: An FTC Survey," Staff Report of the Bureau of Economics and Consumer Protection, Federal Trade Commission.

---- (2013), “Consumer Fraud in the United States, 2011: The Third FTC Survey,” Staff Report of the Bureau of Economics, Federal Trade Commission.

Bass, Frank M. (1969), "A New Product Growth Model for Consumer Durables," Management Science, 15(5), 215-227.

Bertrand, Marianne and Adair Morse (2011), "Information Disclosure, Cognitive Biases, and Payday Borrowing," Journal of Finance, LXVI (6), 1865-1893.

Biggart, Nicole Woolsey (1990), "Capitalism in Contrasting Cultures: Direct Selling in the U.S. and Asia," in Capitalism in Contrasting Cultures, Gordon Redding and Stewart Clegg (eds.) New York and Berlin: Walter de Gruyter, 409-.

Blackmore, Susan (2000), The Meme Fountain, Oxford: Oxford University Press.

Brodie, Stewart, John Stanworth, and Thomas Wotruba (2002), "Comparisons of salespeople in multilevel vs. single level direct selling organizations," Journal of Personal Selling and Sales Management, 22(2), 67-76.

Cahn, Peter (2006), "Building down and dreaming up: Finding faith in a Mexican multilevel marketer," American Ethnologist, 33(1), 126-142.

----- (2008), "Consuming class: Multilevel marketers in neoliberal Mexico," Cultural Anthropology, 23(3), 429-452.

Casanova, Erynn Masi de (2011),"Multiplying themselves: Women cosmetic sellers in Ecuador," Feminist Economics, 17(2), 1-29.

Cialdini, Robert B. (2001), Influence: Science and Practice, Boston, MA: Allyn and Bacon.

Dennett, Daniel C. (1995), Darwin's Dangerous Idea: Evolution and the Meaning of Life, New York: Simon and Schuster.

Direct Selling Association (2014), "Direct Selling 411," (accessed January 22, 2014), [available at http://www.directselling411.com/]

Fairfax, Lisa M. (2001), "'With Friends Like These . . .': Toward A More Efficacious Response To Affinity-Based Securities And Investment Fraud," Georgia Law Review, 36(1), 63.

Federal Trade Commission (2011), "Business Opportunity Rule," Federal Register/ Vol. 76, No. 236 / Rules and Regulations, 16 CFR Part 437, RIN 3084-AB04. 
Federal Trade Commission (2012), " FTC Concludes Regulatory Review of Cooling Off Rule; Proposes Increase in Threshold Amount for Coverage by the Rule from $\$ 25$ to $\$ 130$ Worth of Consumer Goods or Services," (Press Release) Retrieved from http://www.ftc.gov/news-events/pressreleases/2012/12/ftc-concludes-regulatory-review-cooling-rule-proposes-increase.

Federal Trade Commission (2013a), "Consumer Sentinel Network Data Book for January December 2012," Retrieved from http://www.ftc.gov/enforcement/consumer-sentinelnetwork/reports.

----- (2013b), "Kentucky AG and FTC Press Conference on Fortune Hi-Tech Marketing," (Press Release) Retrieved from http://www.youtube.com/watch?v=EBY9UXBbtWc.

Federal Trade Commission v. BurnLounge, Inc. (2014), "Appeal from the United States District Court for the Central District of California," United States Court of Appeals for the Ninth Circuit, 12-55926, 12-56197, and 12-56228.

Federal Trade Commission, State of Illinois, Commonwealth of Kentucky, and State of North Carolina v. Fortune Hi-Tech Marketing, Inc. (2013a), "Complaint for Permanent Injunction," United States District Court for the Northern District of Illinois Eastern Division, 13cv578.

---- (2013b), "Declaration of Kaitlin A. Dohse," United States District Court for the Northern District of Illinois Eastern Division, 13cv578.

---- (2013c), "Declaration of Peter J. Vander Nat," United States District Court for the Northern District of Illinois Eastern Division, 13cv578.

---- (2013d), "Report of Temporary Receiver's Activities: January 24, 2013 through February 19, 2013," United States District Court for the Northern District of Illinois Eastern Division, $13 \mathrm{cv} 578$.

Federal Trade Commission, State of Illinois, Commonwealth of Kentucky, and State of North Carolina v. Fortune Hi-Tech Marketing, Inc. (2014a), "Order," United States District Court Eastern District of Kentucky Central Division at Lexington, Civil Action No. 13-123-KSF.

Federal Trade Commission, State of Illinois, Commonwealth of Kentucky, and State of North Carolina v. Fortune Hi-Tech Marketing, Inc. (2014b), "Stipulated Order for Permanent Injunction and Monetary Judgment," United States District Court for the Northern District of Illinois Eastern Division, 13cv578.

Fischer, Peter, Stefan Schulz-Hardt, and Dieter Frey (2008), "Selective exposure and information quantity: How different information quantities moderate decision makers' preference for consistent and inconsistent information," Journal of Personality and Social Psychology, 94(2), 231-244.

Garrison, Loretta, Manoj Hastak, Jeanne M. Hogarth, Susan Kleimann, and Alan S. Levy (2012), "Designing Evidence-based Disclosures: A Case Study of Financial Privacy Notes," The Journal of Consumer Affairs, 46(2), 204-234.

Gastwirth, Joseph L (1977), "A Probability Model of a Pyramid Scheme," The American Statistician, 31(2), 79-82. 
----- and P.K. Bhattacharya (1984), "Two Probability Models of Pyramid or Chain Letter Schemes Demonstrating That Their Promotional Claims Are Unreliable," Operations Research, 32(3), 527-536.

Goffman, Erving (1952), "On Cooling the Mark Out: Some Aspects of Adaptation to Failure," Psychiatry: Journal of Interpersonal Relations, 15(4):451-63.

Grimes, Paul W., Kevin E. Rogers, and Rebecca Campbell Smith (2010) "High School Economic Education and Access to Financial Services," The Journal of Consumer Affairs, 44(2), 317-335.

Haggith, Mandy, Ravi Prabhu, Carol J. Pierce Colter, Bill Ritchie, Alan Thomson, and Happyson Mudavanhu (2003), "Infectious Ideas: Modelling the Diffusion of Ideas Across Social Networks," Small-scale Forest Economics, Management and Policy, 2(2), 225-239.

Huang, Cun-Yao, and Hau-Ning Chen (2010), "Global Digital Divide: A Dynamic Analysis Based on the Bass Model," Journal of Public Policy and Marketing, 29(2), 248-264.

Jarvis, Chris (1999), "The rise and fall of the pyramid schemes in Albania," IMF Working Paper 99/98, International Monetary Fund.

Keep, William W., and Peter J. Vander Nat (2014), "Multilevel Marketing and Pyramid Schemes in the United States: An Historical Analysis," Journal of Historical Research in Marketing, 6(2), forthcoming.

Kohm, J. A. (2004), "Re: Staff Advisory Opinion - Pyramid Scheme Analysis," letter to N.H. Offen, President, Direct Selling Association, 14 January.

Langenderfer, Jeff, and Terence A. Shimp (2001), "Consumer vulnerability to scams, swindles and fraud: A new theory of visceral influences on persuasion," Psychology and Marketing, 18(7), 763-783.

Lynch, Aaron (1996), Thought Contagion, New York: Basic Books.

Mahajan, Vijay, Eitan Muller, and Frank M. Bass (1995), "Diffusion of New Products: Empirical Generalizations and Managerial Uses," Marketing Science, 14(3), G79-G88.

McGregor, Sue L.T. (2000), "Consumer Education and the OECD Electronic Commerce Consumer Protection Guidelines," Journal of Consumer Studies and Home Economics, 24(3), 170-178.

McGregor, Sue (2005), "Sustainable Consumer Empowerment Through Critical Consumer Education: A Typology of Consumer Education Approaches," International Journal of Consumer Studies, 29(5), 437-447.

McGregor, Sue L.T. (2012), "Complexity Economics, Wicked Problems and Consumer Education," International Journal of Consumer Studies, 36(1), 61-69.

Montana v. Fortune Hi-Tech Marketing, Inc. (2010), Commissioner of Securities and Insurance, Office of the State Auditor, State of Montana, SEC-2010-12. 
O'Mahoney, Joseph (2007), "The Diffusion of Management Innovations: The Possibilities and Limitations of Memetics," Journal of Management Studies, 44(8), 1324-1348.

Perri, Frank S., and Richard G. Brody (2011), "Birds of the Same Feather: The Dangers of Affinity Fraud," Journal of Forensic Studies in Accounting and Business, 3(1), 33-46.

Peterson, Mark (2013), Sustainable Enterprise: A Macro-Marketing Approach. Thousand Oaks, CA: SAGE Publications, Inc.

Pratt, Michael G. (2000), "The Good, the Bad, and the Ambivalent: Managing Identification among Amway Distributors," Administrative Science Quarterly, 45(3), 456-493.

Redmond, William H. (1996), "Product Disadoption: Quitting Smoking as a Diffusion Process," Journal of Public Policy \& Marketing, 15(1), 87-97.

Rogers, Everett M. (1962), Diffusion of Innovations, New York: Free Press.

----- (1976), "New Product Adoption and Diffusion," Journal of Consumer Research, 2(4), 290301.

Royston, Patrick and Richard Goldstein (1993), "An Improved R-squared," STB Reprints, 3, 9498.

Schwartz, Martin L. (1992), "Direct Selling: A Multinational Strategy," Journal of Marketing Channels, 2(2), 79-94.

State of Montana (2013), "Montana Code Annotated 2013," (accessed June 9, 2014), [available at http://leg.mt.gov/bills/mca/30/10/30-10-324.htm].

Vander Nat, Peter, and William Keep (2002), "Marketing Fraud: An approach for differentiating multilevel marketing from pyramid schemes," Journal of Public Policy and Marketing, 21(1), 139-151.

Verdery, Katherine (1995), "Faith, hope and Caritas in the land of the pyramids: Romania 1990 to 1994," Comparative Studies in Society and History, 37(4), 625-669.

Walstad, William B., Ken Rebek, and Richard A. MacDonald (2010) "The Effects of Financial Education on the Financial Knowledge of High School Students,'The Journal of Consumer Affairs, 44(2), 336-357.

World Federation of Direct Selling Associations (2012), "Global Statistical Report and Global Report on Sales Strategies and Compensation Methods," (accessed August 25, 2012), [available at http://www.wfdsa.org/about_wfdsa/?fa=globalStats]. 
Table 1. FHTM Distributor Data (June, 2006 - March, 2010) - High and Low Earners

\begin{tabular}{|c|c|c|c|c|c|c|c|c|c|c|}
\hline City & County & $\begin{array}{l}\text { Join } \\
\text { Date } \\
\end{array}$ & $\begin{array}{c}\text { Join } \\
\text { Fee } \\
\end{array}$ & $\begin{array}{c}\text { Renewal } \\
\text { Fees } \\
\text { Paid } \\
\end{array}$ & $\begin{array}{c}\text { Trainer } \\
\text { Coach } \\
\text { Fees } \\
\end{array}$ & $\begin{array}{c}2007 \\
\text { Commissions } \\
\text { Paid } \\
\end{array}$ & $\begin{array}{c}2008 \\
\text { Commissions } \\
\text { Paid } \\
\end{array}$ & $\begin{array}{c}2009 \\
\text { Commissions } \\
\text { Paid } \\
\end{array}$ & $\begin{array}{c}\text { YTD 2010 } \\
\text { Commissions } \\
\text { Paid } \\
\end{array}$ & $\begin{array}{c}\text { Net } \\
\text { Earnings } \\
\end{array}$ \\
\hline \multicolumn{11}{|c|}{ For Highest 10 Net Earners in Montana } \\
\hline Billings & Yellowstone & 30-Aug-07 & $\$ 299$ & $\$ 398$ & $\$ 299$ & $\$ 2,069.69$ & $\$ 27,130.41$ & $\$ 173,566.86$ & $\$ 38,710.12$ & $\$ 240,481.08$ \\
\hline Laurel & Yellowstone & 12-Jul-06 & $\$ 299$ & $\$ 697$ & $\$ 299$ & $\$ 15,106.82$ & $\$ 65,143.19$ & $\$ 107,127.86$ & $\$ 9,150.56$ & $\$ 195,233.43$ \\
\hline Bozeman & Gallatin & 15-Aug-06 & $\$ 299$ & $\$ 597$ & $\$ 299$ & $\$ 6,319.18$ & $\$ 26,478.32$ & $\$ 39,958.85$ & $\$ 17,021.66$ & $\$ 88,583.01$ \\
\hline Huntley & Yellowstone & 30-Apr-07 & $\$ 299$ & $\$ 440$ & $\$ 299$ & $\$ 1,881.46$ & $\$ 20,358.81$ & $\$ 17,691.63$ & $\$ 21,988.95$ & $\$ 60,882.85$ \\
\hline Bozeman & Gallatin & 30-Jan-09 & $\$ 299$ & $\$ 199$ & $\$ 299$ & & & $\$ 43,571.10$ & $\$ 16,215.52$ & $\$ 58,989.62$ \\
\hline Billings & Yellowstone & 06-Jun-09 & $\$ 299$ & $\$ 0$ & $\$ 299$ & & & $\$ 36,155.20$ & $\$ 18,256.25$ & $\$ 53,813.45$ \\
\hline Billings & Yellowstone & 07-Oct-08 & $\$ 299$ & $\$ 199$ & $\$ 299$ & & $\$ 2,754.08$ & $\$ 45,646.72$ & $\$ 1,237.26$ & $\$ 48,841.06$ \\
\hline Billings & Yellowstone & 15-May-09 & $\$ 299$ & $\$ 0$ & $\$ 299$ & & & $\$ 35,741.98$ & $\$ 6,642.76$ & $\$ 41,786.74$ \\
\hline Billings & Yellowstone & 13-Mar-09 & $\$ 299$ & $\$ 199$ & $\$ 299$ & & & $\$ 34,899.75$ & $\$ 5,602.77$ & $\$ 39,705.52$ \\
\hline Bozeman & Gallatin & 13-Feb-08 & $\$ 299$ & $\$ 398$ & $\$ 299$ & & $\$ 6,678.65$ & $\$ 20,133.16$ & $\$ 3,887.83$ & $\$ 29,703.64$ \\
\hline \multicolumn{11}{|c|}{ For Lowest 10 Net Earners in Montana } \\
\hline Bozeman & Gallatin & 04-Aug-08 & $\$ 299$ & $\$ 0$ & $\$ 299$ & $\$ 0$ & $\$ 0$ & $\$ 0$ & $\$ 0$ & $\$(598)$ \\
\hline $\begin{array}{l}\text { Great } \\
\text { Falls } \\
\end{array}$ & Cascade & 02-Apr-08 & $\$ 299$ & $\$ 0$ & $\$ 299$ & $\$ 0$ & $\$ 0$ & $\$ 0$ & $\$ 0$ & $\$(598)$ \\
\hline $\begin{array}{l}\text { Great } \\
\text { Falls }\end{array}$ & Cascade & 05-Mar-10 & $\$ 308$ & $\$ 0$ & $\$ 299$ & $\$ 0$ & $\$ 0$ & $\$ 0$ & $\$ 0$ & $\$(607)$ \\
\hline Worden & Yellowstone & $12-F e b-10$ & $\$ 308$ & $\$ 0$ & $\$ 299$ & $\$ 0$ & $\$ 0$ & $\$ 0$ & $\$ 0$ & $\$(607)$ \\
\hline Bozeman & Gallatin & 01-Feb-10 & $\$ 308$ & $\$ 0$ & $\$ 299$ & $\$ 0$ & $\$ 0$ & $\$ 0$ & $\$ 0$ & $\$(607)$ \\
\hline Roundup & Musselshell & 19-Nov-09 & $\$ 308$ & $\$ 0$ & $\$ 299$ & $\$ 0$ & $\$ 0$ & $\$ 0$ & $\$ 0$ & $\$(607)$ \\
\hline Billings & Yellowstone & 16-Nov-09 & $\$ 308$ & $\$ 0$ & $\$ 299$ & $\$ 0$ & $\$ 0$ & $\$ 0$ & $\$ 0$ & $\$(607)$ \\
\hline Billings & Yellowstone & 15-Oct-09 & $\$ 308$ & $\$ 0$ & $\$ 299$ & $\$ 0$ & $\$ 0$ & $\$ 0$ & $\$ 0$ & $\$(607)$ \\
\hline Billings & Yellowstone & 19-Sep-09 & $\$ 308$ & $\$ 0$ & $\$ 299$ & $\$ 0$ & $\$ 0$ & $\$ 0$ & $\$ 0$ & $\$(607)$ \\
\hline Billings & Yellowstone & 05-Oct-07 & $\$ 299$ & $\$ 498$ & $\$ 299$ & $\$ 0$ & $\$ 420.95$ & $\$ 29.02$ & $\$ 0$ & $\$(646.03)$ \\
\hline
\end{tabular}




\section{Table 2. FHTM Earnings and Retention in Montana by Joining Year}

Note: All earnings data represents net earnings for participants over the course of their participation with the firm, between their join date and March 10, 2010. As in Table 1 and Figure 1, expenses accounted for only include join, renewal and training fees.

\begin{tabular}{cccccccc} 
Year & $\begin{array}{c}\text { Joined } \\
\text { During } \\
\text { Time } \\
\text { Period }\end{array}$ & $\begin{array}{c}\text { Number } \\
\text { of Joins } \\
\text { in Year }\end{array}$ & $\begin{array}{c}\text { Average } \\
\text { Net } \\
\text { Earnings }\end{array}$ & $\begin{array}{c}\text { Median } \\
\text { Net } \\
\text { Earnings }\end{array}$ & $\begin{array}{c}\text { Zero or } \\
\text { Negative } \\
\text { Net } \\
\text { Earnings }\end{array}$ & $\begin{array}{c}\text { Retention } \\
\text { Rate } \\
\text { (Participated } \\
>1 \text { year) }\end{array}$ & $\begin{array}{c}\text { Retention } \\
\text { Rate } \\
\text { (Participated } \\
>2 \text { years) }\end{array}$ \\
\hline 1 & $\begin{array}{c}\text { June 2006- } \\
\text { May 2007 }\end{array}$ & 92 & $\$ 3,988.74$ & $-\$ 247.41$ & $85.9 \%$ & $21.74 \%$ & $13.04 \%$ \\
2 & $\begin{array}{c}\text { June 2007- } \\
\text { May 2008 }\end{array}$ & 499 & $\$ 496.71$ & $-\$ 287.86$ & $91.8 \%$ & $9.22 \%$ & $2.61 \%$ \\
3 & $\begin{array}{c}\text { June 2008- } \\
\text { May 2009 }\end{array}$ & 734 & $\$ 154.39$ & $-\$ 299.00$ & $89.8 \%$ & $6.27 \%$ & $0.41 \%$ \\
June 2009- & 2,413 & $-\$ 179.86$ & $-\$ 299.00$ & $96.1 \%$ & N/A & N/A \\
March 2010 & & & & & &
\end{tabular}


Table 3. FHTM vs. Other MLM Firms: Results of Time Series Regression Analyses (Quarter 12006 - Quarter 12010 )

\begin{tabular}{|c|c|c|c|c|c|c|c|c|c|c|c|}
\hline & \multicolumn{5}{|c|}{$\begin{array}{l}\text { Negative linear } \\
\text { time trend }\end{array}$} & \multicolumn{3}{|c|}{$\begin{array}{l}\text { Positive linear } \\
\text { time trend }\end{array}$} & \multicolumn{3}{|c|}{$\begin{array}{c}\text { Positive log-linear } \\
\text { time trend }\end{array}$} \\
\hline & $\begin{array}{l}\text { AVON } \\
\text { North } \\
\text { America } \\
\end{array}$ & $\begin{array}{l}\text { Manna-tech } \\
\text { U.S. }\end{array}$ & Reliv U.S. & $\begin{array}{l}\text { Forever } \\
\text { Green }\end{array}$ & $\begin{array}{l}\text { USANA } \\
\text { U.S. }\end{array}$ & $\begin{array}{l}\text { Herbalife } \\
\text { U.S. }\end{array}$ & $\begin{array}{l}\text { Tupper- } \\
\text { ware } \\
\text { North } \\
\text { America } \\
\end{array}$ & $\begin{array}{l}\text { FHTM } \\
\text { in MT }\end{array}$ & Medifast & $\begin{array}{c}\text { Life } \\
\text { Vantage }\end{array}$ & $\begin{array}{l}\text { NuSkin } \\
\text { U.S. }\end{array}$ \\
\hline Intercept & $\begin{array}{l}768.098 * * * \\
(33.200)\end{array}$ & $\begin{array}{l}76.303 * * * \\
(28.563)\end{array}$ & $\begin{array}{l}27.564 * * * \\
(24.895)\end{array}$ & $\begin{array}{l}6.855 * * * \\
(15.881)\end{array}$ & $\begin{array}{l}42.748 * * * \\
(30.507)\end{array}$ & $\begin{array}{l}66.952 * * * \\
(14.621)\end{array}$ & $\begin{array}{l}62.147 * * * \\
(17.969)\end{array}$ & $\begin{array}{l}7.205 * * * \\
(12.799)\end{array}$ & $\begin{array}{l}2.451 * * * \\
(33.890)\end{array}$ & $\begin{array}{l}-.285 \\
(-.970)\end{array}$ & $\begin{array}{l}3.580 * * * \\
(70.490)\end{array}$ \\
\hline Time & $-7.039 * * *$ & $-2.730 * * *$ & $-.651 * * *$ & $-.339 * * *$ & $-.197 *$ & $3.781 * * *$ & $.921 * * *$ & $.329 * * *$ & $.079 * * *$ & $.050 * *$ & $.031 * * *$ \\
\hline & $(-3.941)$ & $(-13.239)$ & $(-7.621)$ & $(-8.622)$ & $(-1.820)$ & (10.697) & (3.449) & (6.613) & (14.200) & $(2.210)$ & $(7.840)$ \\
\hline Recession & 15.252 & -3.315 & -.454 & .853 & .328 & -.150 & -.718 & .128 & $-.192 * * *$ & $-.612 * *$ & .007 \\
\hline & $(.821)$ & $(-1.546)$ & $(-.511)$ & $(2.832)$ & $(.292)$ & $(-.041)$ & $(-.259)$ & $(.278)$ & $(-3.300)$ & $(-2.600)$ & $(.170)$ \\
\hline Quarter1 & $\begin{array}{l}-132.271 * * * \\
(-5.976)\end{array}$ & $\begin{array}{l}-.048 \\
(-.019)\end{array}$ & $\begin{array}{l}3.669 * * * \\
(3.464)\end{array}$ & $\begin{array}{l}-.628 \\
(-1.576)\end{array}$ & $\begin{array}{l}-2.474 * \\
(-1.845)\end{array}$ & $\begin{array}{l}11.259 * * \\
(2.570)\end{array}$ & $\begin{array}{l}-5.147 \\
(-1.556)\end{array}$ & $\begin{array}{l}-.009 \\
(-.015)\end{array}$ & $\begin{array}{l}.277 * * * \\
(4.010)\end{array}$ & $\begin{array}{l}.211 \\
(.750)\end{array}$ & $\begin{array}{l}-.086 \\
(-1.770)\end{array}$ \\
\hline Quarter2 & $\begin{array}{l}-106.465^{* * * *} \\
(-4.438)\end{array}$ & $\begin{array}{l}2.644 \\
(.954)\end{array}$ & $\begin{array}{l}-.517 \\
(-.450)\end{array}$ & $\begin{array}{l}-.566 \\
(-1.281)\end{array}$ & $\begin{array}{l}-.659 \\
(-.453)\end{array}$ & $\begin{array}{l}16.075^{* * *} \\
(3.385)\end{array}$ & $\begin{array}{l}9.221 * * * \\
(2.571)\end{array}$ & $\begin{array}{l}-.437 \\
(-.838)\end{array}$ & $\begin{array}{l}.287 * * * \\
(3.830)\end{array}$ & $\begin{array}{l}.242 \\
(.790)\end{array}$ & $\begin{array}{l}-.050 \\
(-.950)\end{array}$ \\
\hline Quarter3 & $\begin{array}{l}-132.864 * * * \\
(-5.767)\end{array}$ & $\begin{array}{l}-2.155 \\
(-.810)\end{array}$ & $\begin{array}{l}.379 \\
(.343)\end{array}$ & $\begin{array}{l}-.019 \\
(-.046)\end{array}$ & $\begin{array}{l}-1.022 \\
(-.733)\end{array}$ & $\begin{array}{l}14.531 * * * \\
(3.187)\end{array}$ & $\begin{array}{l}3.146 \\
(.913)\end{array}$ & $\begin{array}{l}-.068 \\
(-.139)\end{array}$ & $\begin{array}{l}.177 * * \\
(2.450) \\
\end{array}$ & $\begin{array}{l}.332 \\
(1.130) \\
\end{array}$ & $\begin{array}{l}-.051 \\
(-1.000)\end{array}$ \\
\hline $\mathrm{R}^{2}$ & .838 & .957 & .896 & .918 & .396 & .929 & .739 & .886 & .952 & .466 & .883 \\
\hline $\begin{array}{l}\text { Primary } \\
\text { Business }\end{array}$ & $\begin{array}{l}\text { Cosmetics; } \\
\text { skin care; } \\
\text { beauty } \\
\text { products }\end{array}$ & $\begin{array}{l}\text { Supplements; } \\
\text { weight loss } \\
\text { products; } \\
\text { skin care }\end{array}$ & Supplements & $\begin{array}{l}.860 \\
\text { Weight } \\
\text { loss } \\
\text { products; } \\
\text { personal } \\
\text { care } \\
\text { products }\end{array}$ & $\begin{array}{l}\text { Supplements; } \\
\text { weight loss } \\
\text { products; } \\
\text { skin care }\end{array}$ & $\begin{array}{l}\text { Weight loss } \\
\text { products; } \\
\text { supplements }\end{array}$ & $\begin{array}{l}\text { Container } \\
\text { and other } \\
\text { home } \\
\text { products }\end{array}$ & $\begin{array}{l}.823 \\
\text { Skin care; } \\
\text { supplements; } \\
\text { third party } \\
\text { vendor of } \\
\text { other various } \\
\text { products }\end{array}$ & $\begin{array}{l}\text { Weight } \\
\text { loss } \\
\text { products }\end{array}$ & $\begin{array}{l}\text { Anti- } \\
\text { aging } \\
\text { products }\end{array}$ & $\begin{array}{l}\text { Skin care; } \\
\text { supplements; } \\
\text { anti-aging } \\
\text { products }\end{array}$ \\
\hline
\end{tabular}

Notes: $\quad * * * p<.01, * * p<.05 . * p<.10$

For all 10 comparator companies, quarterly revenue is represented in millions of dollars and obtained from SEC 10Q and 10K filings.

For FHTM, revenue is in dollars and computed from join fees in Montana.

When region is not noted, revenue is for entire company and revenue is dominated by U.S. sales. 


\section{Table 4. Warning Signs of MLM-Based Pyramid Schemes}

Indicator

Source

Little/no demonstrated company revenue from retail sales to public (sales to those outside the MLM program)

Participant income primarily derived from recruitment, rather than sales of products Sales pitch emphasizes recruiting

Excessive earnings claims or promises of high returns in a short time period Product is unproven and/or unfairly priced

Buy-in required

$+* \Delta$

$t^{*} \Delta$

$f^{*} \Delta$

$\ddagger * \Delta$

$+* \Delta$

$\dagger^{*} \Delta$

$* \Delta \diamond$

Vast majority of past participants lose money

No information on potential expenses (in writing)

$* \Delta$

$* \diamond$

$\Delta \diamond$

High turnover of past participants

$\Delta \diamond$

Messages of easy money or passive income

Complex commission structure

Required inventory purchases

Mandatory purchases (beyond want or need) to stay in good standing

No clear refund policy (in writing)

Past legal action against the company

Rapid decline in participation

Growth in participation despite recession

Higher participation in economically depressed regions

* FTC (http://www.consumer.ftc.gov/articles/0065-multilevel-marketing)

+ SEC (https://www.sec.gov/investor/alerts/ia_pyramid.htm)

$\triangle$ Vander Nat and Keep (2002)

$\diamond$ Present paper, from diffusion analysis and connected FHTM Montana data 
Figure 1. FHTM Distributor Net Earnings in Montana (June, 2006 - March, 2010)

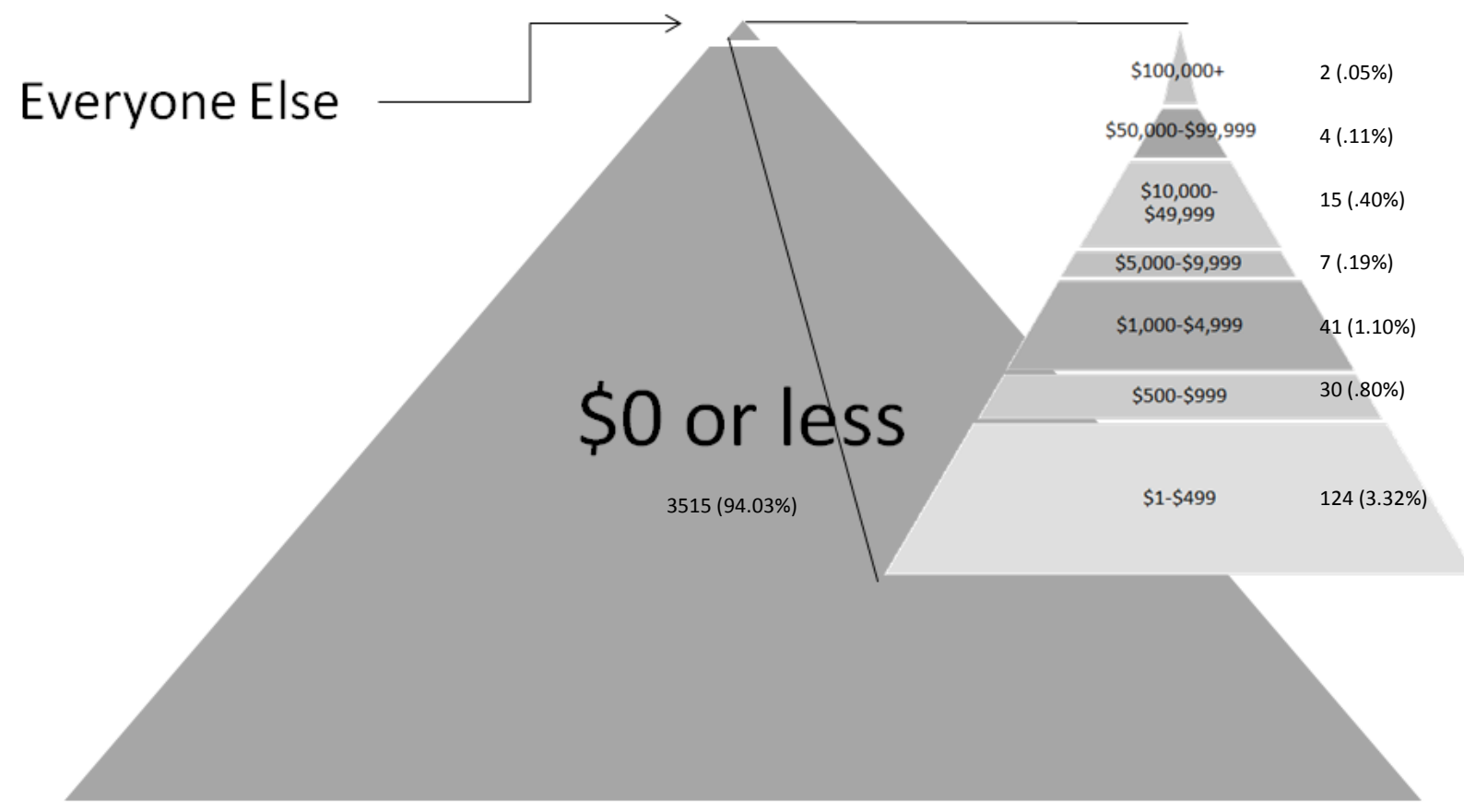




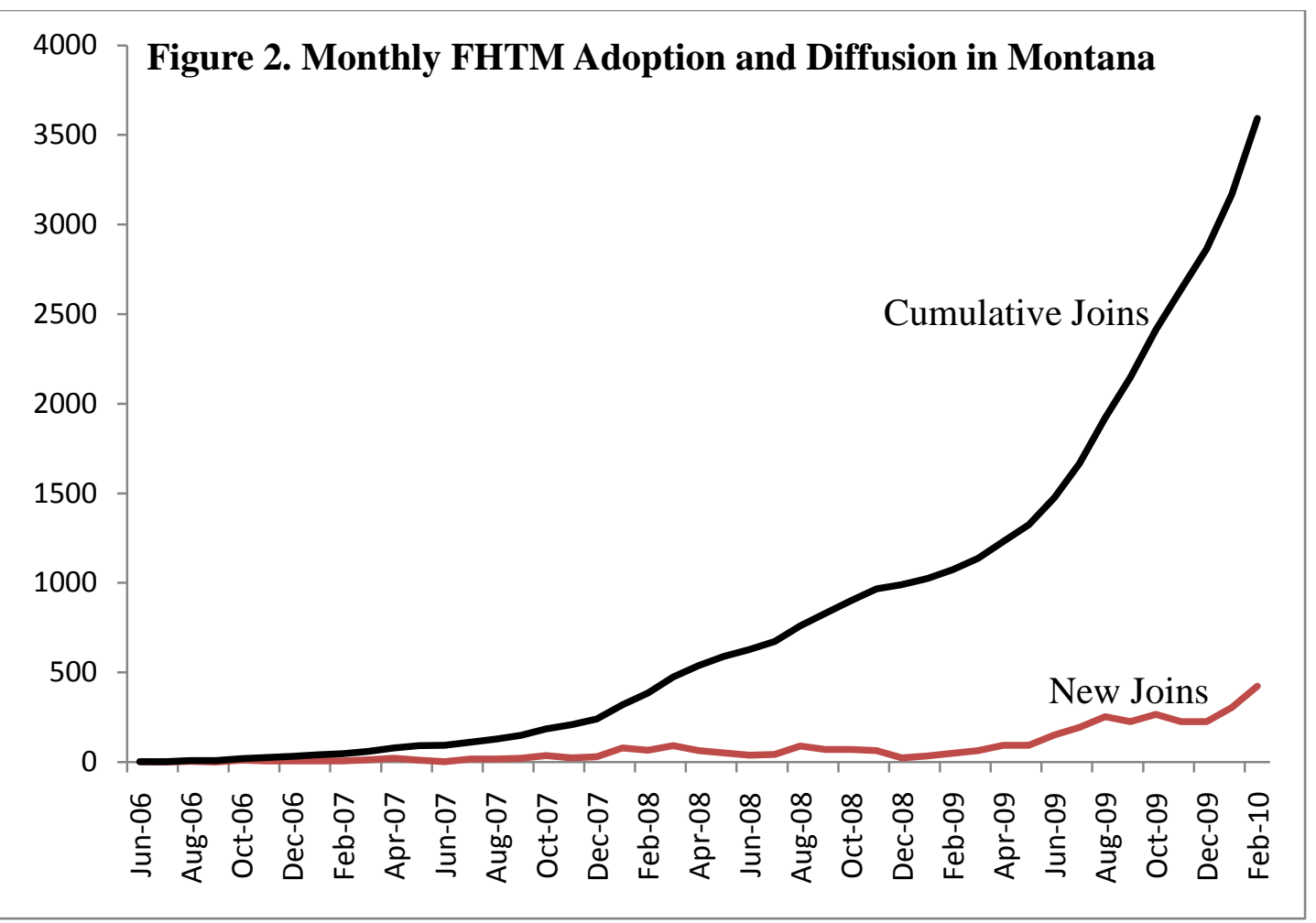




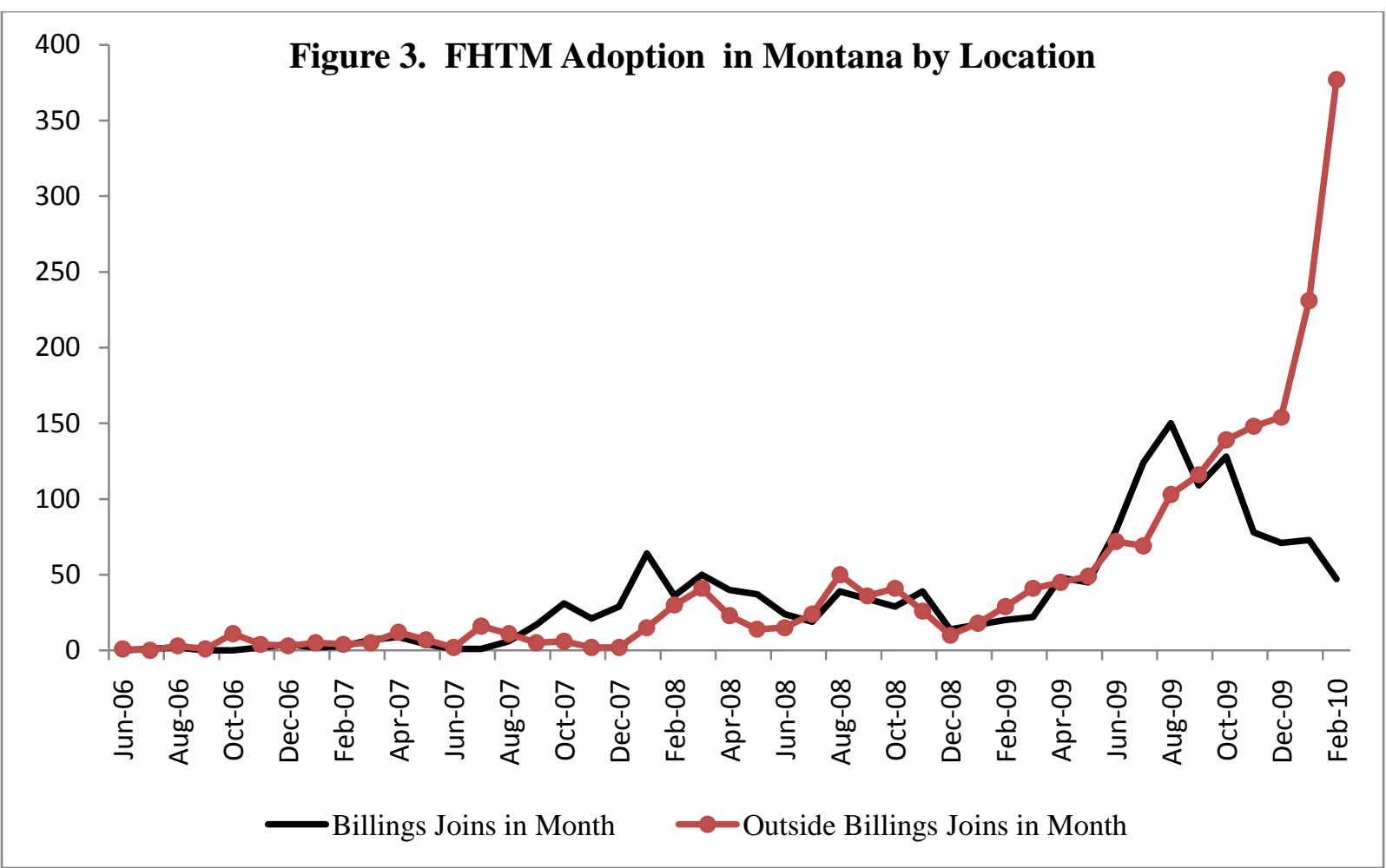




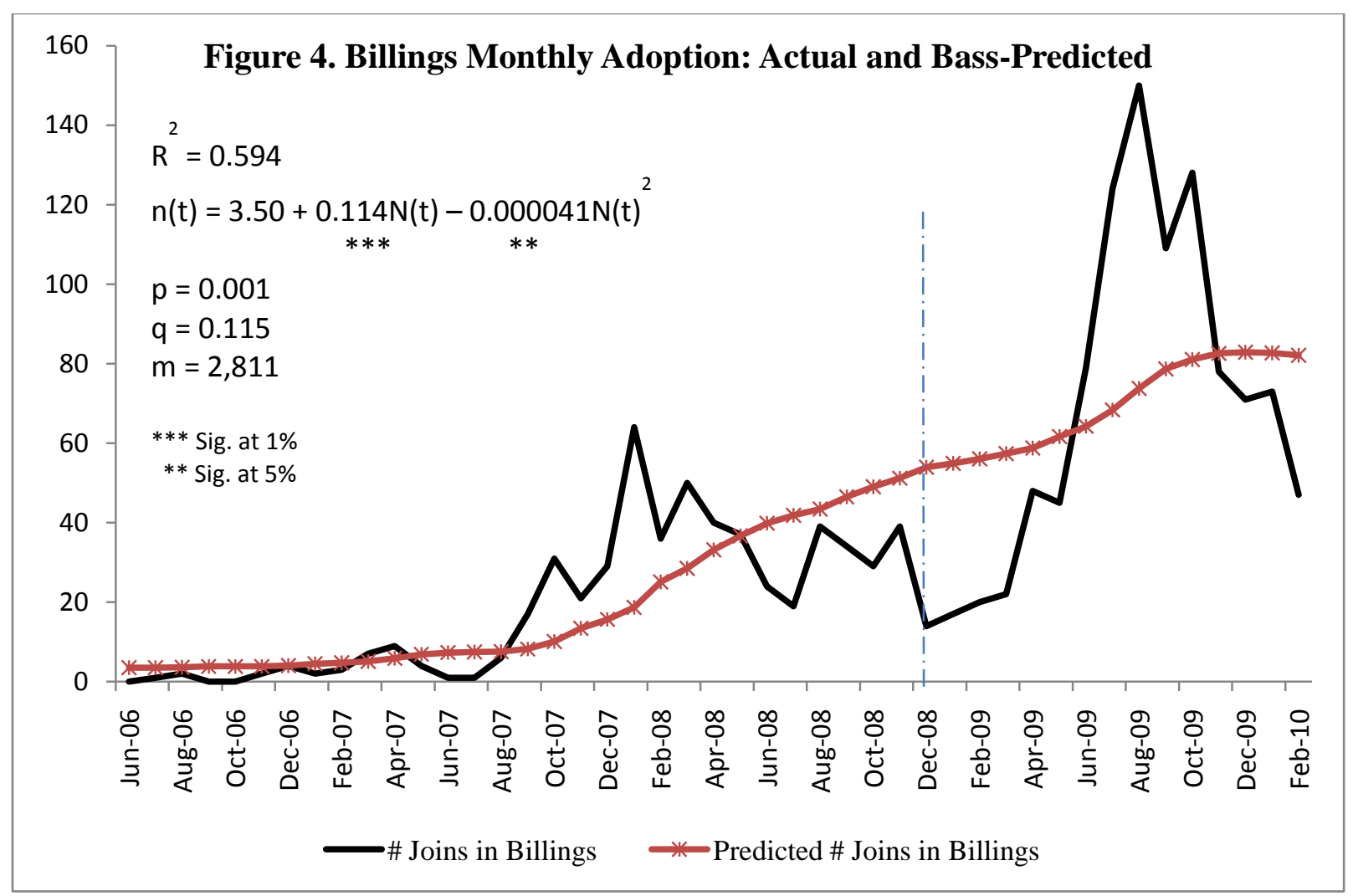




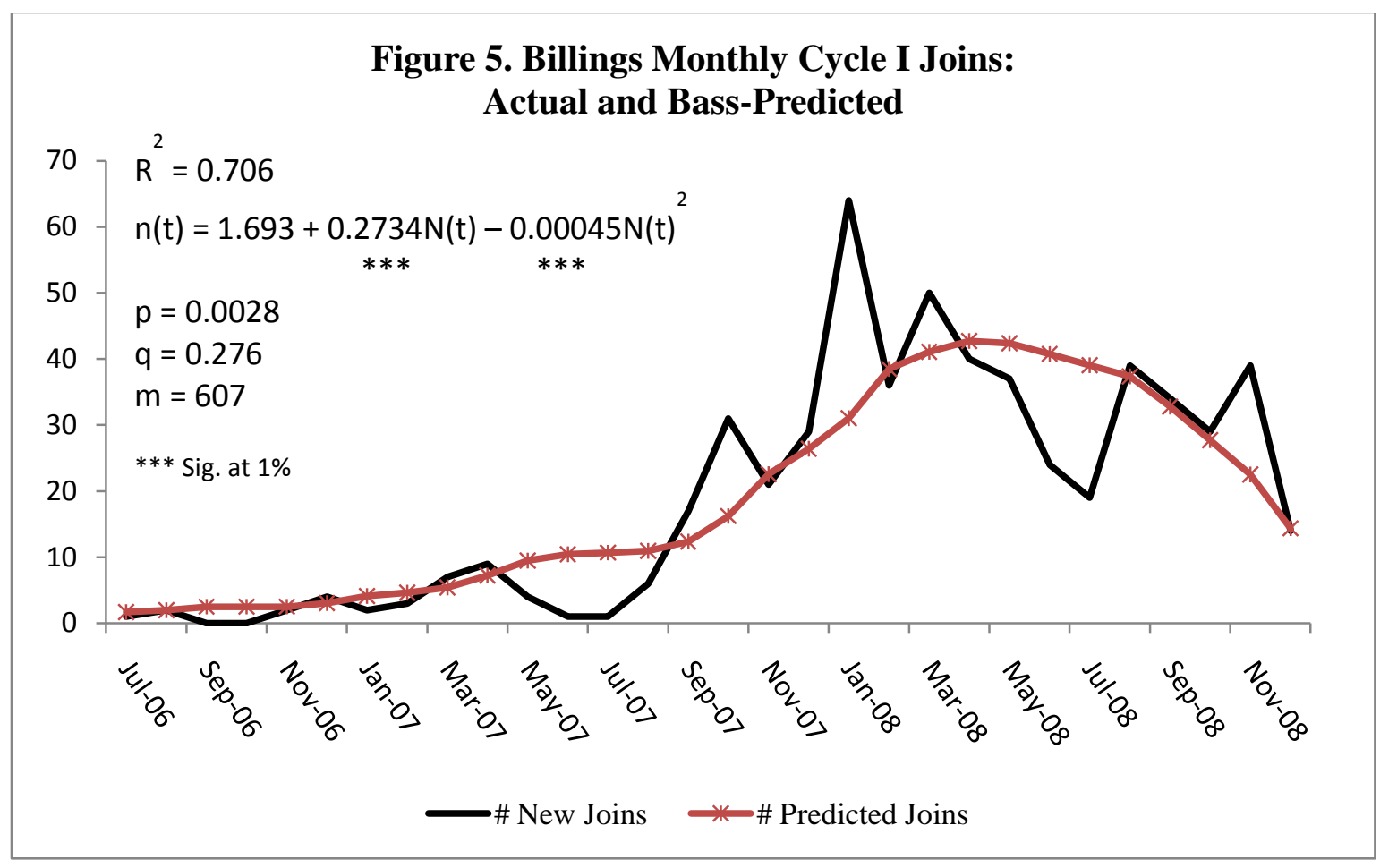




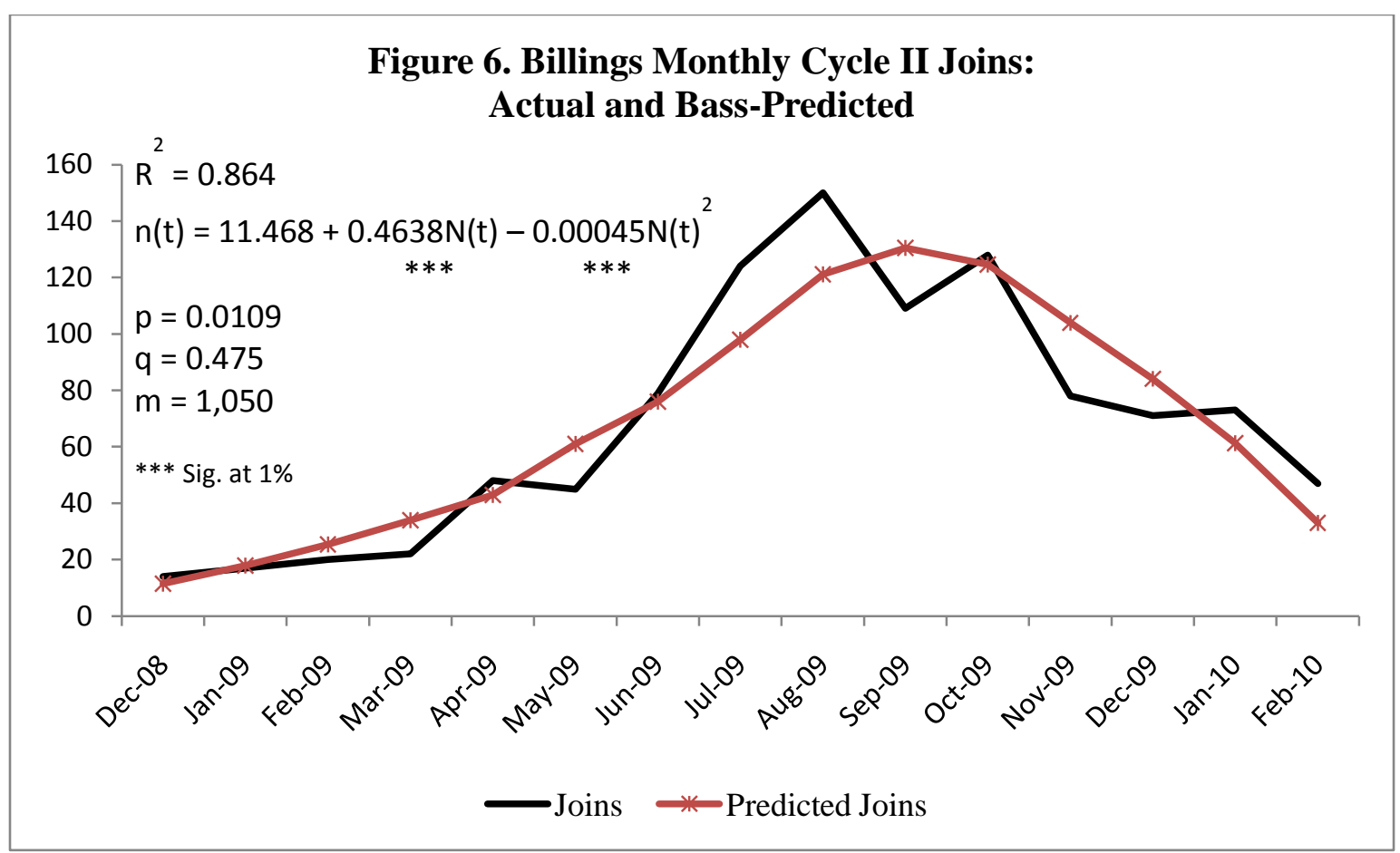




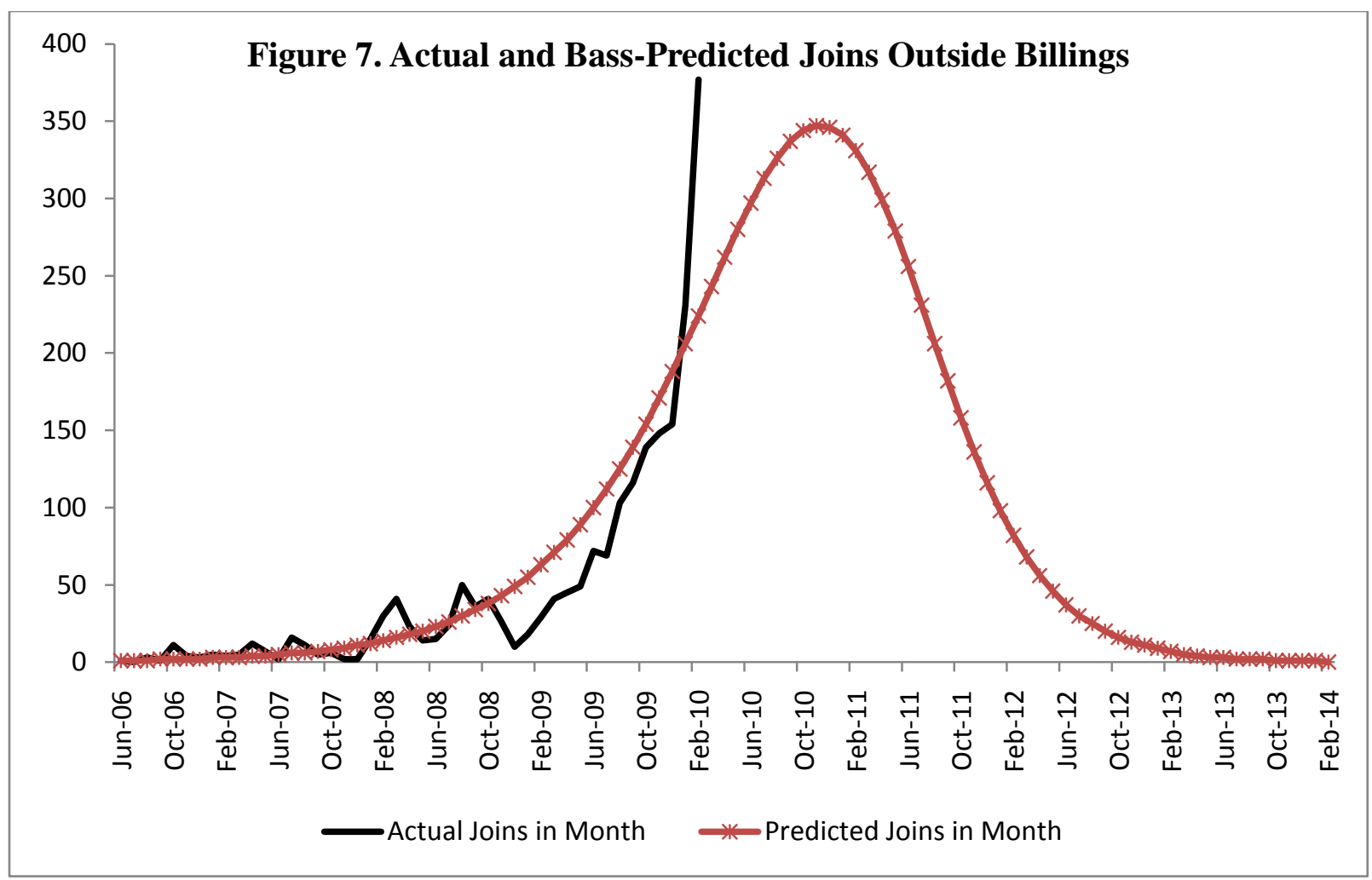


Figure 8. Impact of County-level Economic Conditions on Scheme Contagion (Outside Billings)

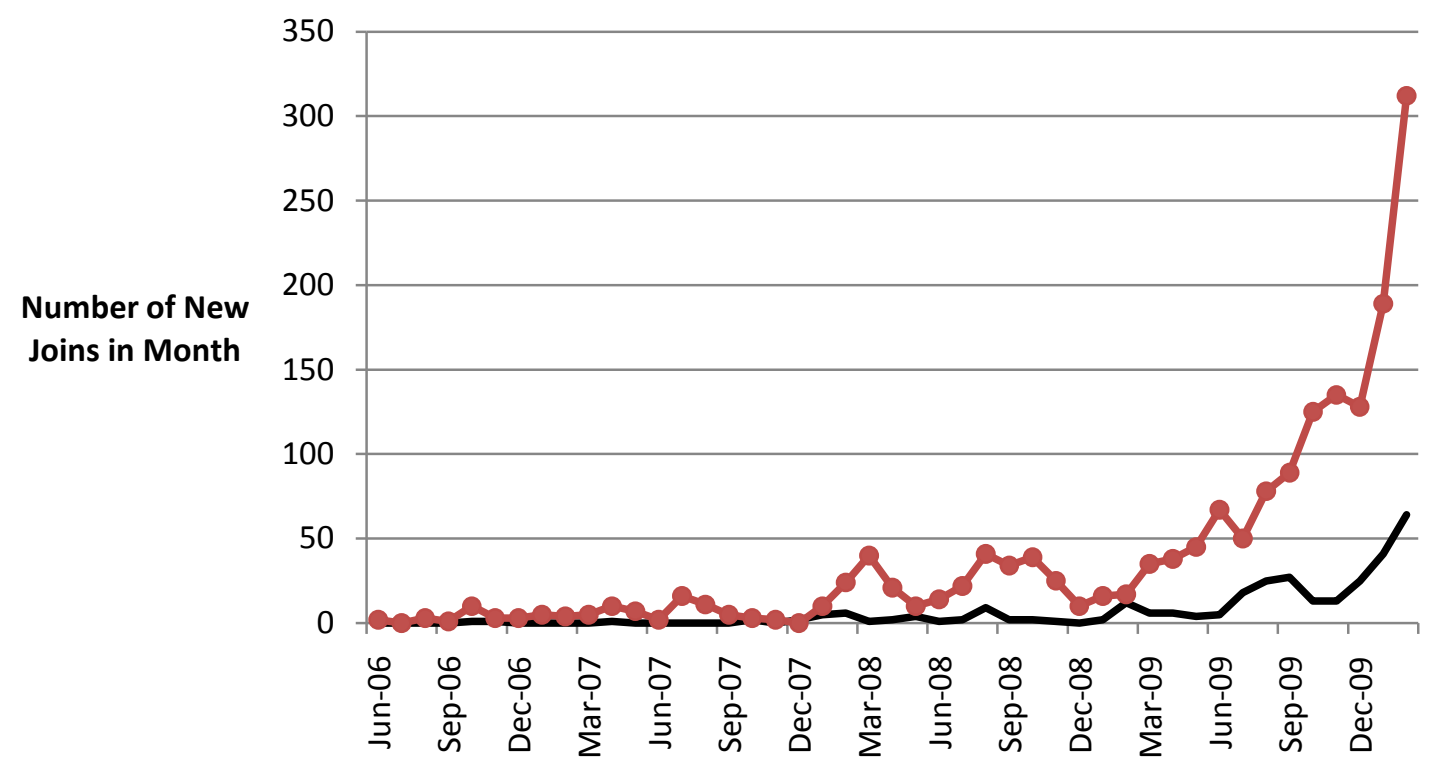

Low Increase in Unemployment Rate (Less than $2.8 \%$ Increase)

High Increase in Unemployment Rate (2.8\% Increase or More) 